\title{
Metastatic lesions to the liver: Surgical indications and techniques
}

\author{
Luis Tejedor ${ }^{1}$, Alejandro Serrablo² \\ 1. General Surgery Department, Punta Europa Hospital, Algeciras, Spain. 2. HPB Surgical Unit, Miguel Servet University \\ Hospital, Zaragoza, Spain. \\ Correspondence: Alejandro Serrablo. Address: HPB Surgical Unit, Miguel Servet University Hospital, Zaragoza, Spain. \\ Email: almaley@telefonica.net
}

Received: September 17, 2013 Accepted: December 5, 2013

DOI : $10.5430 /$ jst.v4n1p11

URL: http://dx.doi.org/10.5430/jst.v4n1p11

Online Published: December 29, 2013

\section{Abstract}

Background: Although there is an established agreement on the advantage of liver resection for metastatic colorectal and neuroendocrine tumours, the role of hepatic surgery in patients with liver metastases from non-colorectal and non-neuroendocrine carcinoma is not well defined. In recent years, despite the poor results, liver metastases suitable for surgery have been treated with resection. The results reported in recent studies support a developing trend toward surgery in this setting. Also, as there are no data that in fact suggest the utility of alternative treatments for these lesions, the role of surgery is reinforced.

Methods: A systematic search of English and non-English literature using MEDLINE on the outcomes of patients after surgical treatment of liver metastases from different solid tumours was undertaken. A summary of current surgical techniques used to improve their resectability has been added.

Results: All papers reporting median survival and 5-year survival have been selected and presented in tables for most of the primary tumours reviewed.

Conclusions: Apart from patients with colorectal and neuroendocrine tumours, liver resection may offer a significative survival advantage in selected patients, mainly those with metastases coming from breast, gastrointestinal stromal tumours, testis, ovary and kidney.

\section{Key words}

Liver metastases, Surgery for liver metastases, Liver resection techniques

\section{I ntroduction}

Surgery is clearly indicated for treatment of liver metastases from colorectal and neuroendocrine tumours but it's not plainly established for metastases from others primaries, since survival results after liver resection of these later cases have been uniformly poor. However, during the last decade a valuable number of reports showed better survival after this surgery, so that a rethinking on the management of these conditions is considered worthwhile.

We carried out a systematic search of papers reporting survival outcomes of these patients after hepatic resection, trying to clarify the surgical indications for these lesions. Unfortunately, but also as expected, most of the reports are retrospective, include a short number of patients, and the biases in the selection of its patients are difficult to estimate. 


\section{Surgical indications in metastatic lesions to the liver}

\subsection{Colorectal cancer}

The liver is the organ most frequently involved and often the sole site of metastasis in colorectal cancer. In $20 \%-25 \%$ of the patients colorectal liver metastases (CLM) are present at the time of diagnosis while around $40 \%$ of the patients are diagnosed after resection of the primary tumour ${ }^{[1]}$. CLM are limited to one lobe in less than one third of patients and are solitary lesions in only $10 \%$ of cases.

Without treatment, median survival is less than eight months. Survival with untreated CLM at five years is unusual (0-3\%) but increases to $35 \%-58 \%$ after resection with curative intent ${ }^{[2]}$. Hepatic resection offers the only chance of long-term survival for patients with CLM. The first large series concluding that there is a benefit for surgery in selected patients with CLM was reported in $1978^{[3]}$. The 5-year survival rate for these patients has increased from about $30 \%$ two decades ago to nearly $60 \%$ nowadays, with a 10 -year overall survival of $20 \%-25 \%$ for radically resected patients ${ }^{[4]}$ (Table 1 ).

Table 1. Liver resections for CLM

\begin{tabular}{lllll}
\hline Author & Year & N patients & Median survival & 5-year survival \\
\hline Minagawa $^{[5]}$ & 2000 & 235 & - & 38 \\
Bolton $^{[6]}$ & 2000 & 165 & - & 36 \\
Figueras $^{[7]}$ & 2001 & 235 & 51 mo & 36 \\
Choti $^{[8]}$ & 2002 & 133 & 46 mo & 58 \\
Okano $^{[9]}$ & 2002 & 152 & - & 67 \\
Abdalla $^{[10]}$ & 2004 & 190 & - & 58 \\
Fernandez $^{[11]}$ & 2004 & 100 & 22 mo disease-free & 58 \\
Pawlik $^{[12]}$ & 2005 & 557 & $>49$ mo & 58 \\
Wei $^{[13]}$ & 2006 & 423 & 53 mo & 47 \\
Shah $^{[14]}$ & 2007 & 841 & 48 mo & 43 \\
Tanaka $^{[15]}$ & 2008 & 277 & - & 45 \\
Rees $^{[16]}$ & 2008 & 929 & 42 mo & 36 \\
De Jong $^{[17]}$ & 2009 & 1669 & 36 mo & 47 \\
Morris $^{[18]}$ & 2010 & 3116 & - & 44 \\
\hline
\end{tabular}

Surgery is becoming safer (operative mortality rate is less than 1\%) and new systemic therapies increase patient survival. Some strategies may increase the amount of liver remaining after resection. The old criteria for resectability have been surpassed, expanding the indications for resection.

Although all patients with CLM are classified as having stage IV disease in the TNM classification of liver tumours, they form a very heterogeneous group (synchronous and metachronous metastases, node-positive and node-negative disease, unilobar and bilobar lesions, and extrahepatic or no extrahepatic disease) with a very variable prognosis. For example, the survival for a patient with a solitary, resectable liver metastasis is better than that for a patient with stage III disease. Several clinical scores attempt to predict more accurately the outcome of these patients ${ }^{[19-23]}$, but their validation is still 
limited. One more recent proposal from the European Colorectal Metastases Treatment Group defines stage IV colorectal cancer as a tumour spreading beyond N2 lymph node status of the primary with added liver-only disease. It is further stratified as A (easily resectable liver metastases), B (resectable liver metastases), C (liver metastases that may become resectable after downsizing) and $\mathrm{D}$ (liver metastases that are unlikely to become resectable) depending on treatment approach and prognosis. Furthermore, a stage V, A and B, refers to resectable and unresectable disease, respectively, outside of the liver ${ }^{[24]}$. Currently, restratification, particularly the grid staging system ${ }^{[25]}$, is based on the resectability of hepatic and extrahepatic metastases.

\subsection{Neuroendocrine tumours}

Gastrointestinal neuroendocrine tumours (NETs), either carcinoid or pancreatic histological subtypes, originate throughout the gastrointestinal tract. They show a relatively slow rate of growth and the potential to produce a variety of hormones. NETs of pancreatic origin can be non-functioning or can produce hormonally active substances such as insulin, gastrin, vasoactive intestinal peptide and others. Carcinoid tumours arise commonly in the midgut and may secret serotonin and other bioactive amines.

Almost $10 \%$ of all liver metastases are neuroendocrine in origin. Liver is the most common organ involved, followed by bone and lung ${ }^{[26]}$. Most of patients will have disseminated disease at the time of diagnosis and a 5-year survival between $50 \%$ and $80 \%$. Liver metastases of NETs (LMNETs) occur in $50 \%$ to $75 \%$ of small-bowel carcinoids, in $5 \%$ to $70 \%$ of foregut carcinoids and in $14 \%$ of hindgut carcinoids. In many patients this is the only site of metastatic disease for a prolonged period of time. LMNETs are usually multifocal, bilobars and involve more than $50 \%$ of the liver parenchyma in more than half of the cases ${ }^{[27]}$, but hepatic resection achieves an almost doubled 5-year survival rate compared with the non-resected patients $\left(47 \%-82 \%\right.$ vs. $30 \%-40 \%$, respectively) ${ }^{[28]}$.

There is not a firm consensus on the optimal treatment strategy of LMNETs, although some guides have been published $^{[29,30]}$

Table 2. 2007 Consensus guidelines for the treatment of liver metastases from neuroendocrine tumours

\begin{tabular}{ll}
\hline Liver metastasis for NETs & Management \\
\hline & $\begin{array}{l}\text { Surgical resection of both primary and all liver metastasis } \pm \text { local ablative } \\
\text { techniques }\end{array}$ \\
If unresectable or poor surgical candidate: continued biotherapy, hepatic artery \\
chemoembolization (TACE) or embolization and radiofrequency ablation (RFA) \\
Liver transplantation considered in rare cases
\end{tabular}

Biotherapy or other systemic nonsurgical treatment

Palliative treatment if symptoms progress

If small number of isolated liver metastases less than $3 \mathrm{~cm}-4 \mathrm{~cm}$ :

RFA, TACE or embolization; may consider minor or anatomic resection in selected cases.

LMNET with extrahepatic disease

If complex (bilobar) pattern of liver metastases: RFA, or embolization; may consider major liver resection together with RFA for selected cases.

If diffuse pattern of liver metastases: TACE or embolization.

Several studies have shown 5-year survival rates of up to $86 \%$ in R0 resection for both primary and secondary sites (Table 3). Cytoreduction is useful as a palliative approach but it needs to reach at least $90 \%$ of tumour volume reduction to improve both survival and symptoms ${ }^{[31]}$. 
Normalization of tumour markers after surgery, 5-hydroxyindoleacetic acid (5-HIAA) and chromogranin A, predict a complete resection. When radiofrequency ablation (RFA) is the only treatment, relief of symptoms is obtained in $60 \%$ of the cases and local control in $80 \%$, although the length of response is short. Transarterial chemoembolization (TACE), contraindicated when the tumour size exceeds $50 \%$ of the liver due to the risk of liver failure, also has a short duration of response. There is also a risk of causing carcinoid tumour lysis syndrome or crises.

Table 3. Liver resection for neuroendocrine liver metastases

\begin{tabular}{lllll}
\hline Author & Year & N patients & \% free of symptoms & 5-year survival \\
\hline Yao $^{[32]}$ & 2001 & 16 & - & 70 \\
Coppa $^{[33]}$ & 2001 & 20 & - & 67 \\
Jaeck $^{[34]}$ & 2001 & 13 & 100 & 68 \\
Nave $^{[35]}$ & 2001 & 31 & - & 86 \\
Sarmiento $^{[31]}$ & 2003 & 170 & 96 & 61 \\
Knox $^{[36]}$ & 2003 & 13 & 82 & 85 \\
Touzios $^{[27]}$ & 2005 & 19 & 95 & 72 \\
Musunuru $^{[37]}$ & 2006 & 13 & 100 & 83 \\
Norton $^{[38]}$ & 2003 & 16 & 100 & 82 \\
Elias $^{[39]}$ & 2003 & 47 & - & 71 \\
Osborne $^{[40]}$ & 2006 & 61 & 91 & 80 \\
Hibi $^{[41]}$ & 2006 & 21 & 100 & 41 \\
Gomez $^{[42]}$ & 2007 & 18 & 100 & 86 \\
Landry $^{[43]}$ & 2008 & 23 & - & 75 \\
Chambers $^{[44]}$ & 2008 & 30 & 86 & 74 \\
Ahmed $^{[45]}$ & 2009 & 50 & - & 74 \\
\hline
\end{tabular}

The role of liver transplantation in patients with LMNETs remains controversial, especially given the shortage of donors. Few liver transplants have been performed for LMNETs (less than $1 \%$ of the total) and, outside of a few small studies, survival does not seem to have improved. Frilling et al suggests some criteria for transplantation of these patients: age younger than 65, primary tumour under control, absence of extrahepatic disease proven over a 6-month period, progression of liver tumours and excessive hormonal symptoms refractory to medical therapy ${ }^{[46]}$.

Although long-term cure can only be achieved in a small proportion of patients with malignant NETs, significant long-term palliation can be achieved. An aggressive surgical approach may also lead to long-term survival in these patients.

\subsection{Non-colorectal non-neuroendocrine tumours}

After colorectal origin, pancreas, breast, ovary and stomach are the following sources of liver metastasis in decreasing order of frequency ${ }^{[47]}$. The usefulness of liver resection seems clear for metastatic colorectal and neuroendocrine tumours but is much less apparent for non-colorectal non-neuroendocrine (NCRNNE) carcinoma. Many reasons support this insight. Most reported series are not comparable in terms of mid- and long-term (tumour-free) survival, as they include patients with NCRNNE hepatic metastases from different primary malignancies, different frequency of isolated hepatic metastases, different tumoral behaviour, and different sensitivity to chemotherapy and different length of disease-free interval between the resection of the primary tumour and the diagnosis of the liver metastases. In addition, many studies 
include recruitment periods of 10 years or more so the chemotherapy scheme has substantially changed. The conclusions are that prognostic factors for liver metastases from NCRNNE should be taken with caution.

Before surgery, disease-free interval from the primary tumour must be considered. Twelve months is considered as generic minimum period between primary tumour and secondary disease to give an indication for surgery for liver metastases. After this first year, any further time interval should be considered as a progressively increasing positive prognostic factor. A longer disease-free interval is believed to indicate less aggressive tumour biology or a lower account of tumoral stem-cells ${ }^{[48]}$.

In a retrospective study of 1452 patients treated at 41 centres, Adam et al demonstrated that liver resection for NCRNNE hepatic metastases is safe and effective. The authors categorized the outcome according to the primary tumour and the 5-year survival after liver resection into: favourable (adrenal, testicular, ovarian, small bowel, ampullary, breast, renal, and uterine tumours); intermediate (gastric adenocarcinoma, exocrine pancreas, cutaneous melanoma, choroidal melanoma, and duodenal tumours); and poor (gastroesophageal junction, pulmonary, esophageal, and head and neck tumours) ${ }^{[49]}$ (Table 4).

Table 4. Liver resection for NCNNE liver metastases

\begin{tabular}{llll}
\hline Author & Year & N patients & 5-year survival \\
\hline Harrison $^{[50]}$ & 1997 & 96 & 37 \\
Hemming $^{[51]}$ & 2000 & 37 & 45 \\
Laurent $^{[52]}$ & 2001 & 39 & 35 \\
Yamada $^{[53]}$ & 2001 & 33 & 12.1 \\
Cordera $^{[54]}$ & 2005 & 64 & 30 \\
Ercolani $^{[55]}$ & 2005 & 142 & 34.3 \\
Adam $^{[49]}$ & 2006 & 1452 & 36 \\
Lendoire $^{[56]}$ & 2007 & 106 & 19 \\
Reddy $^{[57]}$ & 2007 & 360 & 37 \\
O'Rourke $^{[58]}$ & 2008 & 102 & 39 \\
Lehner $^{[59]}$ & 2009 & 242 & 28 \\
Marudanayagam $^{[60]}$ & 2011 & 65 & 25.6 \\
Groeschl $^{[61]}$ & 2012 & 420 & 31 \\
\hline
\end{tabular}

Liver resection for NCRNNE liver metastases is still a matter of discussion because only small studies have been carried out in this field and the conclusive outcomes are collective and not specific for each type of tumour. Despite this, some series show long-term outcomes after resection, nearly equivalent to those of colorectal tumours.

\subsubsection{Gastrointestinal stromal tumours}

Gastrointestinal stromal tumours (GIST), the most common mesenchymal neoplasms of the gastrointestinal tract, are thought to come from intestinal pacemaker cells, also known as interstitial cells of Cajal ${ }^{[62,63]}$, and account for $1 \%-3 \%$ of all gastrointestinal malignancies ${ }^{[64]}$. They affect mostly males between the ages of 50 and 70 , and are usually found incidentally at early stages. They also show a broad spectrum of biological behaviours, from indolent to rapidly progressive malignancies ${ }^{[65]}$. Large or advanced lesions may present with a variety of clinical findings, including bleeding, abdominal pain, early satiety, bowel obstruction or perforation. 
The only definitive treatment for GIST is surgical resection. At presentation, approximately half of these tumours have already metastasized. The liver is the most frequent site of metastases and liver metastases are a major determinant of survival. Up to $55 \%-72 \%$ of patients develop hepatic metastasis following complete resection of the primary tumour ${ }^{[66]}$. Treatment includes anthracycline and ifosfamide-based chemotherapy regimes, TACE, surgical resection and hepatic transplantation, but high recurrence rates and poor survival outcomes following hepatic transplantation have been reported. Radical surgical resection, including hepatectomy, is the only potential treatment modality for this clinical condition. Liver resection itself has been shown to prolong survival, especially for patients with small metastasis and a long disease-free interval; a time to metastasis of 2 years has actually been an independent predictor of outcome in a large group of patients with a median survival of 61 months ${ }^{[67]}$.

Imatinib mesylate (Glivec $\AA$ ), a tyrosine kinase inhibitor (TKI), has revolutionized the management of this disease. Imatinib has a significant shrinking effect on GIST and can be used when primary GIST have attained a very large size or are in unfavourable locations, increasing the risk of positive resection margins ${ }^{[68]}$. Imatinib has also become the first line of treatment for recurrent and/or metastatic GIST. Another TKI, sunitinib, achieves responses in imatinib-refractory GISTs. Before the advent of TKIs surgical resection was the primary treatment for hepatic gastrointestinal stromal tumour (GIST) metastases. Although TKIs have improved survival in the metastatic setting, outcomes after multimodal therapy comprised of hepatectomy and TKIs for GIST are unknown. A recent report concludes that this combination therapy is more effective than surgery or TKI therapy alone ${ }^{[69]}$. Resection of GIST liver metastases may be curative when the primary disease has been eradicated and negative surgical resection margins are attained (Table 5).

Table 5. Liver resection for GIST, sarcomas and leiomyosarcomas liver metastases

\begin{tabular}{lllll}
\hline Author & Year & N patients & Median survival & 5-year survival \\
\hline Chen ${ }^{[70]}$ & 1998 & 6 & 39 & NR \\
Lang $^{[71]}$ & 2000 & 18 & 28 & 13 \\
Shima $^{[72]}$ & 2003 & 10 & 39 & 11 (disease-free) \\
Nunobe $^{[73]}$ & 2005 & 18 & 36 & 34 \\
Paulik $^{[74]}$ & 2006 & 36 & 47 & 27 \\
Gomez $^{[65]}$ & 2007 & 11 & NR & 91 \\
\hline
\end{tabular}

In summary, surgical resection with curative intent should be considered when feasible, as it may improve survival outcomes in selected patients. Recurrence of disease can be managed with further surgery, RFA, imatinib mesylate therapy or a combination of these treatment modalities.

\subsubsection{Breast cancer}

Visceral metastases from breast cancer have an unlucky prognosis. Liver metastases are uncommon as the sole site of systemic disease: only $3 \%$ to $11 \%$ of patients have the liver as the single involved organ out of $65 \%$ of breast cancer patients with liver metastases as part of the disseminated disease ${ }^{[75]}$, and even rarer is a solitary metastasis. Around $60 \%$ of responses can be obtained with systemic treatment but long-term survival is unusual, varying from 1 to 15 months ${ }^{[76]}$. Moreover, around $70 \%$ of these liver metastases are negative for hormonal receptors so that chemotherapy is usually the only treatment.

Extrahepatic disease has been considered as a contraindication for liver resection in these patients, but some reports have not found differences in survival between operated patients with or without extrahepatic breast cancer metastases, bearing in mind that most of the these extrahepatic lesions were bone metastases treated with chemotherapy and radiotherapy previously to surgery ${ }^{[77]}$. Other retrospective study of 454 patients operated on for metastatic breast cancer reported that $41 \%$ and $21 \%$ of these patients remain alive at 5 and 10 years, respectively ${ }^{[49]}$. Some series of liver resection for breast 
cancer are shown in Table 6. Differences in outcome among series may merely reflect difference in selection criteria and in tumour biology.

Table 6. Liver resection for breast cancer liver metastases

\begin{tabular}{lllll}
\hline Author & Year & N patients & Median survival & 5-year survival \\
\hline Santoro $^{[78]}$ & 2000 & 15 & NR & 38 \\
Yoshimoto $^{[79]}$ & 2000 & 25 & 34 mo & 27 \\
Selzner $^{[80]}$ & 2000 & 17 & 24 mo & 40 \\
Maksan $^{[81]}$ & 2000 & 20 & NR & 36 \\
Krisat $^{[82]}$ & 2000 & 45 & NR & 36 \\
Pocard $^{[83]}$ & 2001 & 65 & 41 mo & 46 \\
Carlini $^{[84]}$ & 2002 & 17 & 53 mo & 46 \\
Elias $^{[85]}$ & 2003 & 54 & 34 mo & 34 \\
Vlastos $^{[86]}$ & 2004 & 31 & 63 mo & 61 \\
Sakamoto $^{[87]}$ & 2005 & 34 & 36 mo & 16 \\
Ercolani $^{[88]}$ & 2005 & 21 & 42 mo & 25 \\
D'Annibale $^{[89]}$ & 2005 & 18 & $32 \mathrm{mo}$ & 30 \\
Adam $^{[49]}$ & 2006 & 454 & $45 \mathrm{mo}$ & 41 \\
Thelen $^{[90]}$ & 2008 & 39 & NR & 42 \\
Caralt $^{[91]}$ & 2008 & 12 & 36 mo & 33 \\
\hline
\end{tabular}

Resection criteria for liver metastases from breast cancer are not yet clearly defined. Response to chemotherapy appears to be an important predictor of survival following hepatic resection. In Adam's report, patients who remained stable or progressed on prehepatectomy chemotherapy were 3.5 times more likely to die than responders. Indeed, preoperative chemotherapy is a modality to prolong survival and the response can be considered as a selection criteria.

Two prognostic factors have been identified by several authors ${ }^{[83]}$ : prolonged tumour-free interval (1-2 years) between breast cancer surgery and liver metastases diagnosis and no lymph node involvement at the time of breast cancer. Liver surgery should be offered to every patient with a good performance status, with predictable R0 resection and with a long disease-free interval (Figure 1).

In synchronous tumours, disease must be stabilized with chemotherapy. To consider surgery, there should not be extrahepatic disease or it must be a solitary bone metastasis. Surgery can be technically hampered because of the effects of chemotherapy on liver parenchyma. Hilar lymphadenectomy can be considered since positive lymph nodes are frequent, although they do not exclude resection.

Liver recurrence is very high and the best chemotherapy regimen in these cases is to be defined. Survival after resection is longer compared with other treatments, although disease-free time is usually brief.

Some authors suggest that liver resection in highly selected patients may function as a cytoreductive rather than a curative procedure, because breast liver metastasis is considered as a disseminated disease, and as a cytoreductive approach it improves the survival rate. 

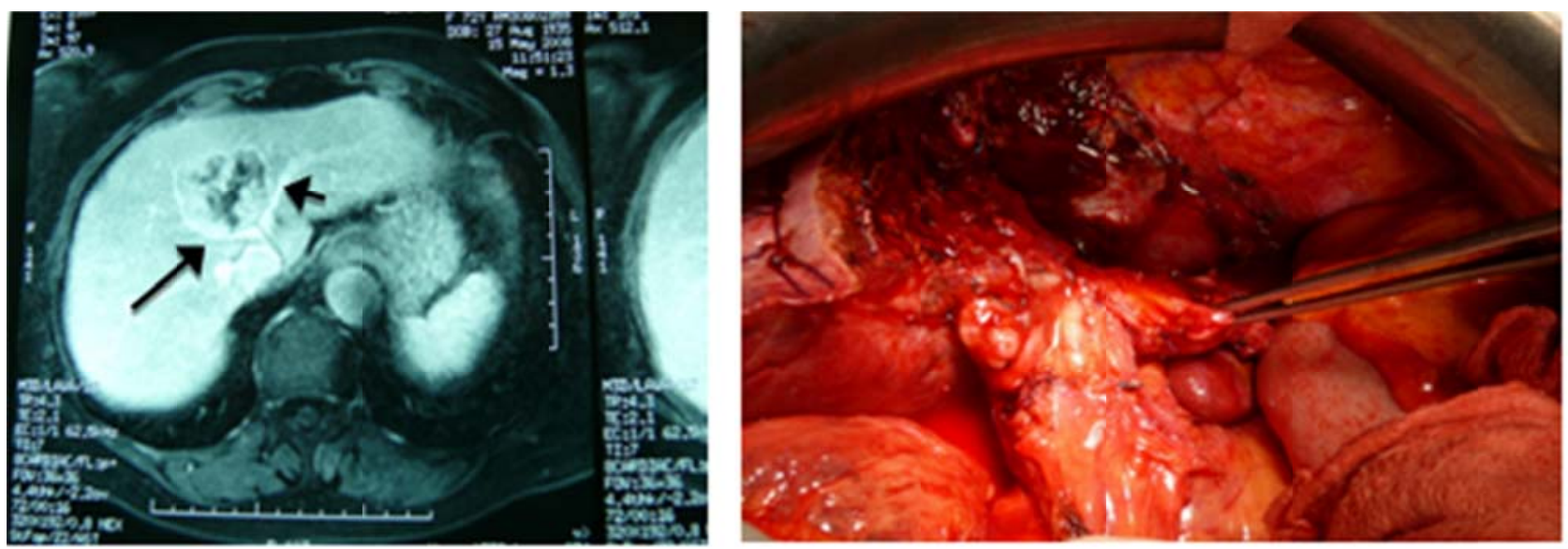

Figure 1. 71 years old woman with a solitary liver metastasis that involved middle (arrow) and left (arrow head) hepatic veins. Sg 2,3,4,5 and 8 have been removed. She is disease-free 5 years after liver resection.

\subsubsection{Melanoma}

Up to $30 \%$ of patients with melanoma develop distant metastases. After lungs and brain, liver is the third most involved organ. Previously considered an infrequent condition, autopsy studies have shown liver metastases in 55\%-75\% of the patients with melanoma ${ }^{[92,93]}$. Mean survival after diagnosis ranges between 2 and 6 months. Single metastases are rare. Diagnosis is generally made by imaging studies during follow-up, since symptoms are suggestive of advanced disease. FDG PET/CT shows a sensitivity of $85 \%$, a specificity of $100 \%$ and a positive predictive value of $98 \%{ }^{[94]}$. Median survival in these patients ranges between 2 and 6 months ${ }^{[95]}$. Palliative radiotherapy and systemic chemotherapy do not prolong survival and, although interferon- $\alpha$ and interleukin- 2 have yielded promising response rates, they are rarely durable ${ }^{[96]}$. New drugs such as vemurafenib, a BRAF kinase inhibitor, seem to achieve longer responses.

Table 7. Liver resection for melanoma liver metastases

\begin{tabular}{lllll}
\hline Author & Year & N patients & Median survival (months) & 5-year survival \\
\hline Rose $^{[93]}$ & 2001 & 24 & 28 & 29 \\
Wood $^{[100]}$ & 2001 & 15 & 14 & 20 \\
Hsueh $^{[101]}$ & 2004 & 24 ocular & 11 & 7 \\
Pawlik $^{[98]}$ & 2006 & 16 ocular & 26 & 20 \\
Crook $^{[102]}$ & 24 cutaneous & NR & 0 \\
Adam $^{[49]}$ & 2006 & 5 & NR & 60 \\
Herman $^{[103]}$ & 2006 & 44 cutaneous & NR & 22 \\
Chua $^{[104]}$ & 2007 & 10 & 22 & 21 \\
\hline
\end{tabular}

A reduction in immunosuppressive factors and a slowing of the growth of occult metastases have been proposed as part of the beneficial effects of liver resection ${ }^{[97]}$ (Table 7). A large series reports a $21 \% 5$-year survival rate for 104 patients after resection of liver metastases from melanoma of choroidal origin and a $22 \% 5$-year survival rate for 44 patients with the same condition but with a cutaneous source ${ }^{[49]}$. The same paper confirmed that choroid melanomas were commonly associated with multiple intrahepatic tumours but were less likely than cutaneous melanomas to be associated with extrahepatic disease. A series collected from four centres showed that the location of the primary tumour substantially 
impacts on the recurrence and survival after resection of secondary liver tumours. Among 40 patients who underwent liver resection, the rate of recurrent hepatic metastases was higher among patients with ocular (53.3\%) compared to those with cutaneous tumours $(17.4 \%)^{[98]}$.

Positive prognostic factors are R0 resection, solitary metastasis and absence of extrahepatic disease ${ }^{[99]}$. Resection with negative margins offers the only chance of long-term survival, since for R1 and R2 resection there are not periods of survival longer than 6 months.

For all the authors, liver resection must not be considered as a curative treatment but as a part of the whole oncologic treatment because of its cytoreductive nature. Reported series during the last decade show that liver resection of metastases from melanoma are infrequent, that the interval between treatment of primary and secondary tumour is long (49 to 96 months), that major hepatectomies are performed in $50 \%$ to $60 \%$ of the patients and that survival varies widely, which indicates that this is a very heterogeneous group of patients with a very variable criteria for resection.

\subsubsection{Gastric cancer and others non-colorectal gastrointestinal adenocarcinoma}

Many reports defend liver resection for metastatic gastric cancer although the indications for resection have not been established. Frequently, liver metastases suggest an advance disease with a mean survival of less than 6 month. Recent studies showed increased survival benefit with 5 -year survivors between $20 \%$ and $60 \%$ (Table 8 ).

Table 8. Liver resection for gastric cancer liver metastases

\begin{tabular}{lllll}
\hline Author & Year & N patients & Median survival & 5-year survival \\
\hline Ambiru $^{[105]}$ & 2001 & 40 & 12 & 18 \\
Fujii $^{[106]}$ & 2001 & 10 & 16 & 10 \\
Imamura $^{[107]}$ & 2001 & 17 & & 0 \\
Zacheri $^{[108]}$ & 2002 & 15 & 9 & 0 \\
Saiura $^{[109]}$ & 2002 & 10 & 25 & 20 \\
Okano $^{[110]}$ & 2002 & 19 & 21 & 34 \\
Shirabe $^{[111]}$ & 2003 & 36 & NR & 26 \\
Roh $^{[12]}$ & 2005 & 11 & 19 & 18 \\
Adam $^{[49]}$ & 2006 & 64 & 15 & 27 \\
Hirai $^{[113]}$ & 2006 & 14 & NR & 42 \\
Sakamoto $^{[114]}$ & 2007 & 37 & 31 & 11 \\
Koga $^{[115]}$ & 2007 & 42 & 34 & 42 \\
Thelen $^{[116]}$ & 2008 & 24 & NR \\
Cheon $^{[117]}$ & 2008 & 22 & 17 & 15 \\
Morise $^{[118]}$ & 2008 & 18 & 13 & 23 \\
Ueda $^{[19]}$ & 2009 & 15 & NR & 27 \\
\hline
\end{tabular}

Positive prognostic factors have been identified: solitary tumour or not more than 3 nodules, size less than $5 \mathrm{~cm}$, unilobar distribution, resection margin more than $10 \mathrm{~mm}$ and disease-free interval between gastric cancer resection and liver metastases longer than 1 year ${ }^{[114]}$. In Thelen's study the multivariate analysis revealed only resection margin as an independent prognostic factor for survival ${ }^{[116]}$. Shirabe concluded that synchronous hepatectomy should not be a contraindication for hepatic resection ${ }^{[11]}$. 
The results of liver resection in liver gastric metastases should not be discarded simply because of the lack of prospective, randomized data. For patients with hepatic disease amenable to surgical resection, treatment alternatives include systemic chemotherapy, locoregional ablative therapies with or without systemic treatment or surgical resection with or without systemic treatment. It is not unreasonable to consider liver resections in highly selected patients as part of multidisciplinary care for this malignancy.

For other non-colorectal gastrointestinal adenocarcinoma (esophageal, biliary, pancreatic cancers) the available evidence for hepatectomy is extremely limited, and this treatment strategy lacks utility. Most authors, despite having performed hepatectomies for these metastatic tumours, agree that it is associated with a poor prognosis. Occasionally, a patient with favourable tumour biology may be identified who will benefit from liver directed therapy.

\subsubsection{Lung cancer}

Liver resection for lung cancer metastases is rare and few numbers of cases are reported in the literature. The reported cases appear frequently associated with other kind of metastatic liver tumour in more large series. Lindlell et al., in the largest series, reported three cases but did not show the outcome ${ }^{[120]}$. Di Carlo reported a case of long-term survival ${ }^{[121]}$.

When a patient has one or two liver nodules with more than one year of disease-free interval from the resection of primary tumour, hepatic resection can be a therapeutic option ${ }^{[122]}$. Liver involvement is managed surgically only under these exceptional circumstances.

\subsubsection{Ovarian and testicular cancer}

Epithelial ovarian cancer is a highly chemosensitive disease, and platinum-based therapies bring about significant diminution of tumour volume in most of the patients. Regrettably, the patients develop resistance to platinum chemotherapy after 24-36 months. Notwithstanding, many centres, despite stage III-IV advanced ovarian cancer, with a median survival of 3.5 years, propose very aggressive management with surgical debulking ${ }^{[123]}$. Multiple studies have shown an important survival benefit when primary cytoreductive surgery precedes the initiation of chemotherapy for advanced ovarian cancer. The benefits of cytoreductive surgery are also obvious in patients with recurrent disease. More than $70 \%$ of patients with advanced stage disease suffer recurrence and the benefits of second debulking depend on chemosensitivity, feasibility of surgery and tumour behaviour.

Liver is rarely the only site of metastatic ovarian cancer but also hepatectomy can be an important point of cytoreduction approach. Ovarian cancer can involve the liver through peritoneal lesions on the surface or with intraparenchymal metastases ${ }^{[124]}$. Survival is clearly improved for stage IV disease patients with complete and adequate debulking, even hepatectomy. Hepatic metastases should not preclude attempts at optimal secondary cytoreductive surgery. When cytoreductive resection is performed by pelvic and hepatobiliary surgeons, morbidity and mortality appear no different from that attributed to aggressive surgical debulking itself.

Metastasectomy is well established in the management of disseminated non-seminomatous germ cell testicular carcinoma that does not completely respond to chemotherapy. The key to success in the treatment of metastatic germ cell tumours is due to the multidisciplinary approach. Although after chemotherapy it can be difficult to differentiate active residual tumour from necrosis or fibrosis, the probability of achieving cure by surgical resection is high. For these reasons, lymphadenectomy and visceral resection are recommended if there is imaging evidence of residual disease ${ }^{[125]}$. In some cases complete excision requires multivisceral radical resections as a last attempt to cure patients who have exhausted all other therapeutic options. Complete surgical resection of all measurable disease is the gold standard and correlates with improvement in both relapse-free and overall survival after hepatectomy, with actuarial survival rates of $78 \%$ at 3 years in these tumours. 


\subsubsection{Renal cell carcinoma and urothelial cancer}

Data on hepatic resection for renal cell cancer (RCC) and urothelial cancer (UC) liver metastases are limited to case reports. In metastatic RCC, the liver involvement is present in $20 \%$ of the patients and carries less than $10 \%$ of overall 1-year survival rate. Furthermore, only $5 \%$ of metastatic RCC patients have the liver as only involved organ. However, five-year survival of 33\% has been reported following resection of lung, brain or lymph node metastases in association with chemotherapy in UC. Furthermore, metastasectomy has been used for palliation with good results ${ }^{[125]}$. However Alves et al. reported 46 liver resections for metastatic RCC patients with a 5 -year survival of $13 \%{ }^{[126]}$.

These limited data determine inconsistent recommendations for hepatectomy in metastatic RCC and UC. In RCC, the use of sunitinib or sorafenib as neoadjuvant or post-hepatectmy therapy could improve the outcome.

\section{Surgical treatment of resectable metastases}

\subsection{Resectability}

Criteria for resectability are derived from the information obtained from the treatment of CLM, but may be applied to the liver metastases from others solid tumours. Pre-operative imaging techniques, patient selection, surgical techniques, postoperative care and new cytotoxic and biologic agents for preoperative and post-operative treatment have dramatically improved the resectability rate of liver metastases. The old criteria for resectability of CLM have accordingly changed: number of metastases is not a risk factor for survival whenever a R0 resection (complete resection with no microscopic residual tumour) is achieved ${ }^{[127]}$. In spite of some conflicting reports, evidence shows that size is not a resectability factor, but a factor related to the aggressiveness of the tumour. Likewise, the width of the surgical margin has no effect on survival providing that the margin is microscopically negative ${ }^{[128-130]}$, though resection should attempt to get an optimum margin.

Few years ago extrahepatic disease was considered a contraindication to liver resection, but 5-year survival rates of $12 \%$ to $37 \%$ after surgery in selected patients, independent of the location of the extrahepatic disease (lung, colorectal recurrence, retroperitoneal or hepatic pedicle lymph nodes, peritoneal carcinomatosis, miscellaneous) have been reported ${ }^{[131-135]}$. Nevertheless, peritoneal disease contraindicates hepatic resection, but it can be considered in cases of stable or responsive disease to chemotherapy and when an $\mathrm{R} 0$ resection is achievable. These patients should be classified as borderline resectable ${ }^{[136]}$. Positive hilar lymph nodes are associated with a 5-year survival rate of 3\%-12\% after resection and are considered as a contraindication to liver resection of CLM, but there may be lengthy survival in some patients as long as the involved nodes are limited to the hepatoduodenal-retropancreatic area ${ }^{[137,138]}$. A positive resection margin is the only traditional prognostic indicator of recurrence that precluded long-term survival ${ }^{[139]}$.

In summary, just two criteria for resectability are significant: all disease should be removed with a negative margin and an adequate hepatic reserve should remain. That is to say, liver metastases are considered as resectable when they can be completely excised, two adjacent liver segments can be spared with an adequate vascular inflow and outflow and biliary drainage, and the volume of the future liver remnant (FLR) is sufficient (at least $20 \%$ of the total estimated volume for liver with normal parenchyma, 30\%-60\% for liver with chemotherapy, steatosis or hepatitis, $40 \%-70 \%$ for liver with cirrhosis) ${ }^{[136]}$. Clinically it is useful to estimate FLR to body weight ratio, which should be greater than 0.5 . Contraindications of resection are non-resectable extrahepatic disease, a Child-Pugh score grade B and C and an inadequate performance status for surgery ${ }^{[25]}$. Notwithstanding, "resectability" of primary or metastatic liver cancer is not a clearly defined issue so that the experience of the individual surgeon plays an essential role.

\subsection{Role of chemotherapy in CLM}

Type of regimen and sequencing of chemotherapies when liver resection of CLM is possible are not clear, since the efficacy of peri-operative chemotherapy on survival for resectable liver metastases has not been justified. There is no evidence to support neoadjuvant chemotherapy in patients with resectable CLM ${ }^{[140]}$. Moreover, since around $7 \%$ of these 
tumours will progress while on chemotherapy, a few patients may be compromised their chance of cure if this treatment is routinely used. Some authors suggest that, in the absence of high-risk features, treatment of CLM should begin with surgery and then consider adjuvant chemotherapy ${ }^{[141]}$. If high-risk features are present (perforated tumour or a considerable lymphatic burden, for instance), most surgeons prefer a course of systemic pre-operative chemotherapy before liver surgery.

The EORTC 40983 study evaluated peri-operative chemotherapy vs. surgery alone in resectable CLM and did not demonstrate a clear advantage of preoperative chemotherapy nor could determine either if neoadjuvant, adjuvant or peri-operative chemotherapy was superior. In this trial, the postoperative complication rate was statistically significantly increased in those patients who receive perioperative chemotherapy versus surgery alone. Supporters of peri-operative treatment point out that surgery is facilitated and that the treatment provides information on tumour biology ${ }^{[142]}$. Livers affected by chemotherapy are usually more rigid, more difficult to manage and tend to bleed more easily at surgery. Moreover, there are some questions to be answered about the management of "ghost lesions" after complete response that cannot be detected with IOUS.

When resection of liver metastases is considered appropriate, it is imperative to have a high quality abdominopelvic CT (or MRI) within a month of the date of surgery. Also a chest CT should be done at that time.

\subsection{Technique}

Intraoperative bleeding is the main cause of postoperative morbidity and mortality. On the other hand, blood transfusion is associated to a higher complication rate, longer hospital stay, increased risk of infectious complications, increased perioperative mortality and decreased long-term survival ${ }^{[143]}$. Thus, it is imperative to have a detailed knowledge of liver anatomy, a control of the vascular inflow and outflow, a low central venous pressure, intraoperative ultrasound and may be some other auxiliary devices (ultrasonic dissection, argon beam coagulation, etc.) to reduce blood loss during the resection.

In general, hepatic segmentectomy is preferable for localize lesions. Non-segmental resection may be technically more difficult and compromise the vascularity of adjacent residual liver. The Brisbane 2000 Terminology of Liver Anatomy and Resections is recommended to avoid confusion in the terms used when describing surgical techniques ${ }^{[144]}$.

Regarding CLM, long-term survival is similar when comparing R1 (microscopically positive margins) with R0, despite a higher recurrence rate (5-year and 10-year overall survival rates are $61 \%$ and $43 \%$ in R0 vs. $57 \%$ and $37 \%$ in the R1) ${ }^{[145]}$. So it can be concluded that the inability to obtain a free surgical margin should not be a contraindication to surgery, as long as a complete macroscopic removal of all metastatic lesions is obtained.

After the first report of a laparoscopic liver resection in $1992^{[146]}$ this approach is more and more frequently performed but, although it shows advantages in the short term over open surgery, there are still no data to indicate the impact of this procedure on long-term outcome.

Liver surgery inflicts a mortality of less than $5 \%$ and a morbidity of around $30 \%$, bearing in mind the wide variation in surgical aggressiveness. Postoperative hepatic failure, which depends on the volume and the function of the residual liver, can be a lethal complication.

Traditionally, a staged approach with initial resection of the primary disease followed by hepatic resection was recommended, but nowadays a simultaneous colon and liver resection is safe and efficient for CLM and LMNETs, since prognosis is not dependent on the time of resection ${ }^{[147-150]}$. Contraindications include the need for primary emergency surgery, a locally advanced colorectal tumour, or the need for major hepatectomy involving three or more segments. For other synchronous metastatic lesions simultaneous surgery can be safe but efficiency is much lower. 
Resection of advanced synchronous liver metastases before resection of the primary disease is another option. The rationale is that it allows a better selection of patients who will benefit from surgery. More importantly, it focuses on the site and may reduce recurrence in the liver at distant sites, which might later occur after treating the primary tumour ${ }^{[151]}$.

\section{Surgical treatment of initially non-resectable metastases}

When metastases are not firstly resectable because of an insufficient FLR, some techniques may be used. Strategies to increase the volume of the hepatic remnant include conversion chemotherapy, portal vein occlusion, staged liver resection and combination of these procedures. Also, ablative techniques may be considered alone or in conjunction with resection.

\subsection{Conversion chemotherapy}

Conversion chemotherapy is directed to downsize the tumour for looking at its resection. New chemotherapeutic regimens for CLM (adding oxaliplatin and/or irinotecan to 5-FU and folinic acid) have achieved response rates of around $50 \%$, enabling $10-30 \%$ of initially unresectable patients to be operated ${ }^{[152]}$. Combined with biologic agents such as bevacizumab (a humanized monoclonal antibody that inhibits vascular endothelial growth factor A, thus impeding angiogenesis) or cetuximab (a monoclonal antibody that inhibits epidermal growth factor receptor in KRAS wild type colon cancer), response rates of up to $70 \%$ are achieved ${ }^{[139]}$.

Hepatic arterial infusion (HAI) of chemotherapy may be added to systemic therapy, obtaining a higher concentration of drugs in the liver with less systemic toxicity but, although response rates are higher than systemic chemotherapy, survival does not change so far. Moreover, its complication rates are so high (57\%) that it is discarded as a first option.

When preoperative chemotherapy is given, a new re-evaluation for resection should be done after 2 or 3 months and every 2 months thereafter. Systemic treatment should be stopped when lesions have been downsized to the point where hepatic resection is possible in order to reduce liver toxicity and to avoid a complete clinical response. A complete response on imaging studies does not mean cure since in over $80 \%$ of the cases of CLM there are viable cancer cells in the initial site of the metastasis ${ }^{[153]}$. Therefore, these ghost lesions have to be removed or ablated ${ }^{[154-156]}$.

Systemic chemotherapy without the resection of bowel disease is associated with a shorter hospital stay and avoids surgery without a detrimental effect on survival for most patients. Medical therapy at the outset avoids the progression of disseminated disease. The development of an endoscopic transtumoral stent used to prevent occlusion is a useful nonsurgical treatment in this case ${ }^{[157]}$.

Tumour progression while under chemotherapy is associated with a poor outcome, even after potentially curative hepatectomy. Hence, tumour control before surgery is crucial ${ }^{[152]}$. Peri-operative complications are more frequent with prolonged pre-operative chemotherapy ${ }^{[158]}$. Since this morbidity affects long-term survival ${ }^{[159]}$, length of chemotherapy treatment must be taken into account.

\subsection{Portal vein occlusion}

Portal vein embolization (PVE), usually of the right portal branch, is directed to induce atrophy of the tumour-bearing lobe with subsequent hypertrophy in the contralateral lobe, by diverting the portal venous flow into the liver part that is expected to remain ${ }^{[160]}$. In general, two methods of portal vein occlusion can be employed: PVE or surgical portal vein ligation (PVL). Neither technique has clear advantage.

Portal occlusion increases the FLR between $10 \%$ to $46 \%$ within 2 to 8 weeks and enables an R0-resection in $70 \%$ to $100 \%$ of selected cases. It increases the chance of liver resection by $19 \%$. However, some patients show tumour progression after PVE. When a hypertrophy greater than $5 \%$ is obtained the risk of a severe post-operative liver insufficiency is low ${ }^{[161]}$. The concomitant administration of chemotherapy does not seem to affect the hypertrophy. 
Percutaneous PVE is usually well tolerated, with a complication rate below $5 \%{ }^{[162]}$. The actuarial survival rate after surgery is $40 \%$ at 5 years, similar to that of patients resected without PVE ${ }^{[163]}$.

\subsection{Two-stage hepatectomy}

When it is impossible to resect all liver metastases in a single procedure, two sequential liver resections may be done. The first surgery attempts to clear out of tumour the FLR, with non-anatomic resections and/or radiofrequency ablation or at most a single segment resection ${ }^{[164]}$. After a period of recovery of 4 to 6 weeks and the hypertrophy of the tumour-free lobe, tumour removal is completed by resection of the larger tumour mass in the contralateral liver lobe. The technique should be well designed in advance to try to achieve a complete removal, although around $30 \%$ of patients will not be rescued on the second hepatectomy because of progression of their disease in the meantime.

Furthermore, a PVE may be performed 2 to 4 weeks after the first stage and the second surgery can be done 4 or 6 weeks later, when a CT confirms an adequate hypertrophy of the non-embolized hemi-liver ${ }^{[165]}$. Alternatively, portal vein occlusion can be done during the first hepatectomy through the ligation and alcoholization of the right portal vein, which is the side more often embolized ${ }^{[166,167]}$.

Patients with a complete resection have a 5-year survival rate of $32 \%-51 \%{ }^{[168,169]}$. Pre-operative chemotherapy may be given during the entire process.

\subsection{Associating Liver Partition and Portal Vein Ligation for Staged Hepatectomy (ALPPS)}

This new technique consists in a two-staged extended right hepatectomy ${ }^{[170]}$. The first stage includes right PVL and in situ splitting (ISS) along the right side of the falciform ligament to induce rapid hypertrophy of the left lateral lobe: a median hypertrophy of $74 \%$ (above that achieved by PVL or PVE alone) after a median time interval of 9 days. This short time interval overrides the risk of tumour progression in the meantime.
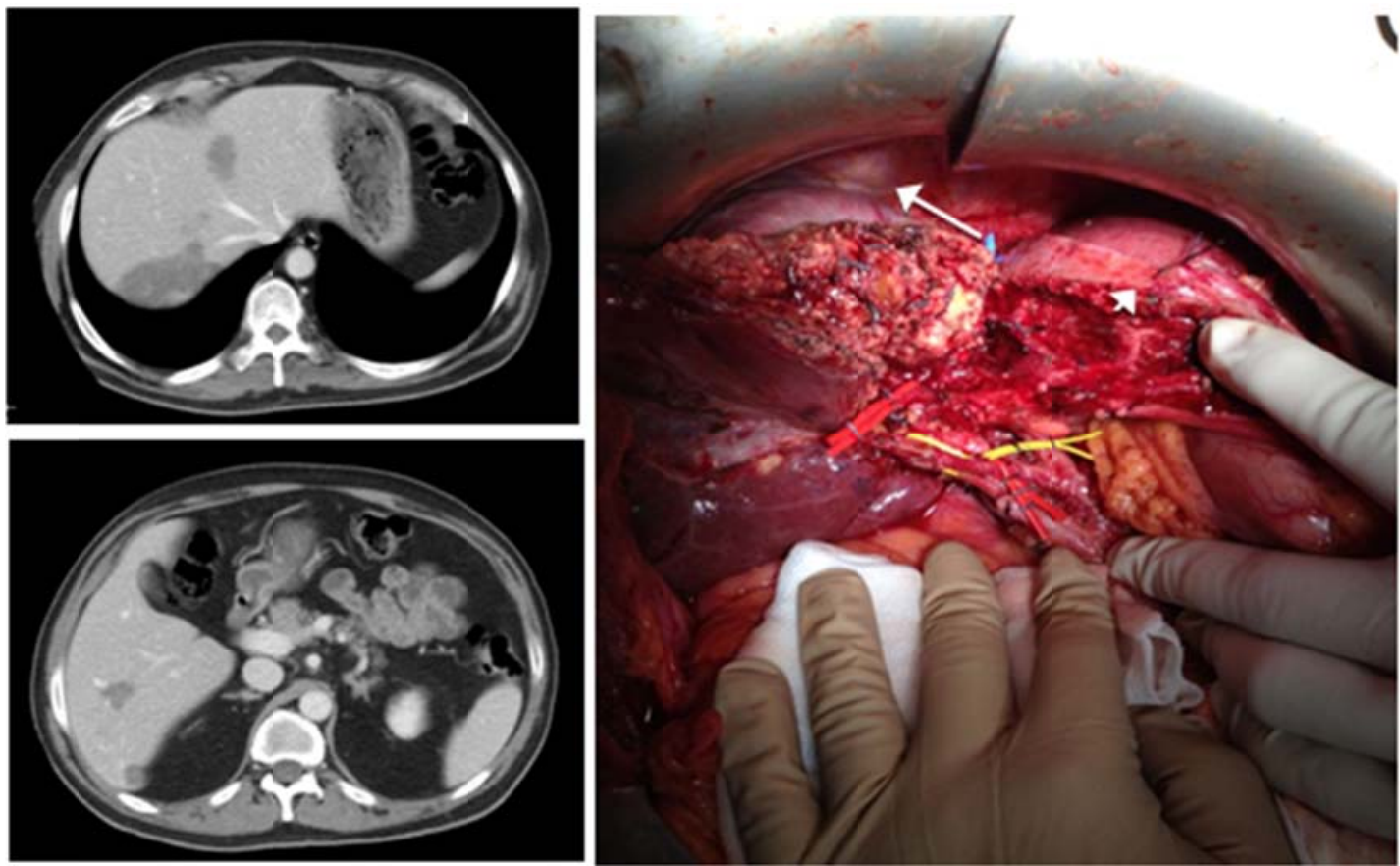

Figure 2. A 46 year-old male with 7 CLM and a FLR of 19.7\%. After 9 cycles of chemotherapy, a FLR of $31.3 \%$ was achieved and an ALPPS was performed. CT showing CLM in Sg 4, 8 and 7 (above) and Sg 5-6 and 6 (below). Operative field: liver partition performed between $\mathrm{Sg} 4-8$ (arrow) and $\mathrm{Sg}$ 2-3 (arrow head) 
The technique is directed to patients with marginally resectable or primarily nonresectable primary and metastatic tumours. When an extended right hepatectomy is planned, the completeness of segment IV branch embolization may frequently be incomplete and progression of the segment IV tumour may impair a second stage.

Some drawbacks of ALPPS are an increased morbidity and mortality rates in the first reported series ${ }^{[171]}$, a necrotic segment 4 in patients who could not be candidates for second stage because of insufficient hypertrophy ${ }^{[172]}$ and little advantages over the previous techniques ${ }^{[173]}$. Advantages of ALPPS include an easier second procedure, a faster recovery for the patient, and the option of performing the colorectal resection simultaneously with the first step of the procedure, including the tumour cleaning of the FLR ${ }^{[174]}$.

Additional research should be addressed about short- and long-term results, accelerated development of micrometastases on the future remnant liver, systemic stress responses affecting the second step of resection, and survival and progression patterns ${ }^{[175]}$, to uncover the oncologic benefit of this new approach. With this purpose, a registry of these cases has been created $^{[176]}$ (Figure 2).

Laparoscopy has also been used in this technique, showing that it is feasible and may be worthwhile in experienced hands ${ }^{[177,178]}$.

\subsection{Ablative techniques}

Radiofrequency ablation (RFA) is obtained by the pass of alternating current across the lesion using a needle placed in the centre of the metastasis. The frictional heat causes coagulative necrosis and irreversible tissue injury. Vessels situated next to the ablated tissue interfere with the ablative techniques by the "heat sink effect". RFA treatment can achieve a 3-year survival rate of $25 \%$. The combination of RFA and systemic chemotherapy has been shown to attain a 5 -year survival rate of $30 \%{ }^{[179,180]}$.

Morbidity and mortality are quite low (17\% and $0.5 \%$, respectively ${ }^{[181]}$.

Laser-induced thermotherapy (LITT) consists in the local administration of laser light to the tumour through fibers of quartz crystal. Morbidity and mortality are similar to RFA. Local tumour control at 6 months is reached in approximately $97 \%$ of the patients ${ }^{[182]}$.

In microwave ablation (MWA), microwaves agitate water molecules in the tissue and produce frictional heat. Transmission is not limited by tissue desiccation and charring as in RFA, allowing higher intratumoral temperatures, a larger ablation zone, shorter treatment time, and more complete tumour killing. Five-year survival rates of $32 \%$ have been reported.

High-intensity focused ultrasound (HIFU) is administered with a lens-focused transducer that elevates the tissue temperature to $60^{\circ} \mathrm{C}$. In addition, the mechanical effects of the high intensity ultrasound assist the destruction of the tumour cells. Adverse effects seem to be minor ${ }^{[183]}$.

Cryotherapy uses liquid nitrogen or argon to cool tumour tissue down to $-180^{\circ} \mathrm{C}$. The formation of intracellular ice crystals leads to a mechanical destruction of the interstitium. An "ice-cracking" of the liver tissue is seen in 5 to $28 \%$ of the patients receiving the treatment. Five-year and 10 -year survival rate of $44 \%$ and $19 \%$ are reported, respectively ${ }^{[184]}$, but local recurrence and high complication rates $(30 \%)$ have led to a diminishing use of this technique.

Despite these data, the precise role of ablative therapy is yet to be established. Patients with serious comorbidity and patients who decline surgery are good candidates, although there are significant risks. Patients with treatable extrahepatic disease or whose tumours have been downsized by chemotherapy but are not resectable may be also considered for ablative therapy. 


\subsection{Total vascular exclusion (TVE) procedures}

Liver transplantation, reduced adult-sized liver for children, living related donor liver transplantation and split liver transplantation are techniques useful in liver resection. Tumours regarded as unresectable with standard techniques can be removed using in-situ, ante-situ and ex-situ or bench liver surgery. These techniques are based in the TVE of the liver and the perfusion of the organ by preservation hypothermic solution. They differ in the extent to which liver is mobilized from its vascular connections, hilum and caval vein. Usually, a veno-venous bypass is employed and a hypothermic preservation solution is instilled through the portal vein, which leads to a better tolerance to ischemia ${ }^{[185]}$.

Tumours that involve vascular structures of the hilum, venous confluence or inferior vena cava (IVC) are the main indications. In the ante-situ procedure the division of the suprahepatic vena cava allows rotation of the liver around the coronary axis, providing optimal exposition of the venous confluents and the retrohepatic vena cava. In the ex-situ technique the liver is completely removed from the patient, allowing complex reconstructions of hepatic veins or portal structures, after which the liver is reimplanted. This procedure was described by Pichlmayr in 1988 and has been sparingly applied in selected patients ${ }^{[186,187]}$ due to its high morbidity and mortality.

Since the IVC can be resected and reconstructed with an autogenous vein graft or a prosthetic material, its involvement does not necessarily preclude resection. High morbidity and mortality rates ( $40 \%$ and $4.5 \%-25 \%$, respectively) should be balanced by the possible benefits, particularly when the lack of alternative approaches is considered ${ }^{[188]}$.

\subsection{Re-resection: repeat hepatectomy}

Recurrence may occur in up to $75 \%$ of CLM resected patients, $92 \%$ of them within the first 24 months after resection ${ }^{[189]}$. Although a half of these relapses are in the liver ${ }^{[190]}$, only $5 \%-27 \%$ of the patients are considered for a repeated hepatectomy.

Each case of recurrent metastatic liver tumour needs a particular and specific evaluation. Although the prognostic variables provide rough indicators of prognosis, they should not be used as absolute contraindications to surgery.

Recurrence after repeat hepatectomy in CLM has been reported in $60 \%-80 \%$ of patients ${ }^{[191]}$. Some patients may be candidates for a third or even fourth hepatic resection. Between $9 \%$ and $30 \%$ of patients with a second hepatectomy have a third resection ${ }^{[19,192-194]}$ and around $4 \%$ of them have a fourth resection ${ }^{[195]}$.

The safety of multiple repeated hepatic resections has been demonstrated, with a low mortality rate $(0-2 \%)$ and a morbidity rate of 5\%-30\%. LiverMet Survey published the largest series $(\mathrm{n}=251)$ of third hepatectomies for CLM showing a survival benefit of $29 \%$ at 5 years.

\subsection{Associated extrahepatic disease (EHD)}

Patients with liver metastasis and EHD have been considered as a subgroup with a very poor prognosis. EHD was traditionally considered a contraindication for liver resection, but survivals of $30 \%$ at 5 years, and higher than that achieved with chemotherapy only, have been obtained in some patients whose CLM and EHD have been resected ${ }^{[196]}$. Moreover, resection improves quality of life of these patients ${ }^{[197]}$.

PET-CT can change the therapeutic approach in up to $25 \%$ of the patients, since infrequent sites of recurrences can be shown (bone, spleen, lymph nodes, etc.) On the other hand, around 5\%-10\% of the patients may benefit from the laparoscopic approach, which can detect peritoneal disease ${ }^{[198]}$. Treatment for patients with resectable CLM and EHD usually begin with 4 to 6 cycles of chemotherapy. If there is clinical response or stable disease, surgery is indicated. Progression contraindicates surgery. 
When EHD is found during surgery (lymph nodes or peritoneal disease) the indication of resection becomes controversial ${ }^{[199]}$.

There are few series of patients with CLM and EHD ${ }^{[200-204]}$. EHD was diagnosed preoperatively just in $40-65 \%$ of the cases. Morbidity and mortality were similar to that of resection of CLM (22\%-31\% and 0-4\%, respectively). Up to $90 \%$ of the patients received postoperative chemotherapy. Five-year survival rate was $0-28 \%$. Recurrence, usually in liver and lungs, appeared in $70 \%-95 \%$ of the patients, and was occasionally resected.

\section{Conclusions}

Aside from patients with colorectal and neuroendocrine tumours, liver resection may offer a significative survival advantage in selected patients. After a minimum disease-free interval of twelve months from the primary tumour, some patients may benefit from this aggressive treatment, mainly those with metastases from breast cancer, gastrointestinal stromal tumours and testicular, ovarian and renal cancer. Resection of metastases from others tumours exhibits shorter long-term survival, although the procedure should be considered on a case-by-case basis, particularly when confronted with the lack of alternative approaches.

\section{References}

[1] Adam R, Wicherts DA, de Haas RJ et al. Patients with initially unresectable colorectal liver metastases: is there a possibility of cure? J Clin Oncol. 2009; 27:1829-35. PMid:19273699 http://dx.doi.org/10.1200/JCO.2008.19.9273

[2] El Khodary M, Milot L, Reinhold C. Imaging of Hepatic Metastases. In: Brodt P (ed.) Liver Metastasis: Biology and Clinical Management. New York: Springer Science+Business Media B.V; 2011: p307-53.

[3] Foster JH. Survival after liver resection for secondary tumours. Am J Surg. 1978; 135: 389-94. http://dx.doi.org/10.1016/0002-9610(78)90072-7

[4] Kopetz S, Chang GJ, Overman MJ, Eng C, Sargent DJ, Larson DW, Grothey A, Vauthey JN, Nagorney DM, McWilliams RR. Improved survival in metastatic colorectal cancer is associated with adoption of hepatic resection and improved chemotherapy. J Clin Oncol. 2009; 27: 3677-83. PMid:19470929 http://dx.doi.org/10.1200/JCO.2008.20.5278

[5] Minagawa M, Makuuchi M, Torzilli G, Takayama T, Kawasaki S, Kosuge T, Yamamoto J, Imamura H. Extension of the frontiers of surgical indication in the treatment of liver metastases from colorectal cancer: long-term results. Ann Surg. 2000; 231:487-99. PMid:10749608 http://dx.doi.org/10.1097/00000658-200004000-00006

[6] Bolton JS, Fuhrman GM. Survival after resection of multiple bilobar hepatic hetastases from colorectal carcinoma. Ann Surg. 2000; 231(5): 743-51. http://dx.doi.org/10.1097/00000658-200005000-00015

[7] Figueras J, Valls C, Rafecas A, Fabregat J, Ramos E, Jaurrieta E. Resection rate and effect of postoperative chemotherapy on survival after surgery for colorectal liver metastases. Br J Surg. 2001; 88: 980-5. PMid:11442531 http://dx.doi.org/10.1046/j.0007-1323.2001.01821.x

[8] Choti MA, Sitzmann JV, Tiburi MF, Sumetchotimetha W, Rangsin R, Schulick RD, Lillemoe KD, Yeo CJ, Cameron JL. Trends in long-term survival following liver resection for hepatic colorectal metastases. Ann Surg. 2002; 235: 759-66. PMid:12035031 http://dx.doi.org/10.1097/00000658-200206000-00002

[9] Okano Y, Yamamoto J, Kosuge T, Ymamamoto S, Sakamoto M, Nakanishi Y, Hirohashi S. Fibrous pseudocapsule of metastatic liver tumours from colorectal carcinoma. Clinicopathological study of 152 first resection cases. Cancer. 2002; 89: 267-75. http://dx.doi.org/10.1002/1097-0142(20000715)89:2<267::AID-CNCR10>3.0.CO;2-1

[10] Abdalla EK, Vauthey JN, Ellis LM, Ellis V, Pollock R, Broglio KR, Hess K, Curley SA. Recurrence and outcomes following hepatic resection, radiofrequency ablation, and combined resection/ablation for colorectal liver metastases. Ann Surg. 2004; 239 : 818-25. PMid:15166961 http://dx.doi.org/10.1097/01.sla.0000128305.90650.71

[11] Fernandez FG, Dnebin JA, Linehan DC, Dehdashti F, Siegel BA, Strasberg SM. Five-year survival after resection of hepatic metastases from colorectal cancer in patients screened by positron emission tomography with F-18 FDG. Ann Surg. 2004; 240: 438-47. PMid:15319715 http://dx.doi.org/10.1097/01.sla.0000138076.72547.b1

[12] Pawlik TM, Scogins CR, Zorzi D, Abdalla EK, Andres A, Eng C, Curley SA, Loyer EM, Muratore A, Mentha G, Capussotti L, Vauthey JN. Effect of surgical margin status on survival and site of recurrence after hepatic resection for colorectal metastases. Ann Surg. 2005; 241: 715-22. PMid:15849507 http://dx.doi.org/10.1097/01.sla.0000160703.75808.7d 
[13] Wei AC, Greig PD, Grant D, Taylor B, Langer B, Gallinger S. Survival after hepatic resection for colorectal metastases: A 10-year experience. Ann Surg Oncol. 2006; 13(5): 668-76. PMid:16523369 http://dx.doi.org/10.1245/ASO.2006.05.039

[14] Shah SA, Bromberg R, Coates A, Rempel E, Simunovic M, Gallinger S. Survival after liver resection for metastatic colorectal carcinoma in a large population. J Am Coll Surg. 2007; 205(5): 676-83. PMid:17964443 http://dx.doi.org/10.1016/j.jamcollsurg.2007.06.283

[15] Tanaka K, Shimada H, Ueda M, Matsuo K, Endo I, Togo S. Role of hepatectomy in treating multiple bilobar colorectal cancer metastases. Surgery. 2008; 143: 259-70. PMid:18242343 http://dx.doi.org/10.1016/j.surg.2007.08.015

[16] Rees MMS, Tekkis P, Welsh F, O'Rourke T, John T. Evaluation of long-term survival after hepatic resection for metastatic colorectal cancer: A multifactorial model of 929 patients. Ann Surg. 2008; 247(1): 125-35. PMid:18156932 http://dx.doi.org/10.1097/SLA.0b013e31815aa2c2

[17] de Jong M, PulitanoC, Ribero D, Strub J, Mentha G, Schulick R, Choti MA, Aldrighetti L, Capussotti L, Pawlik TM. Rates and patterns of recurrence following curative intent surgery for colorectal liver metastasis: An international multi-institutional analysis of 1669 patients. Ann Surg. 2009; 250(3): 440-8. PMid:19730175

[18] Morris EJ, Forman D, Thomas JD, Quirke P, Taylor EF, Fairley L, Cottier B, Poston G. Surgical management and outcomes of colorectal cancer liver metastases. Br J Surg. 2010; 97(7): 1110-8. PMid:20632280 http://dx.doi.org/10.1002/bjs.7032

[19] Fong Y, Fortner J, Sun RL, Brennan MF, Blumgart LH. Clinical score for predicting recurrence after hepatic resection metastatic colorectal cancer: analysis of 1001 consecutive cases. Ann Surg. 1999; 230: 309-18. PMid:10493478 http://dx.doi.org/10.1097/00000658-199909000-00004

[20] Nordlinger B, Guiguet M, Vaillant JC, Balladur P, Boudjema K, Bachellier P. Surgical resection of colorectal carcinoma metastases to the liver. A prognostic scoring system to improve case selection, based on 1568 patients. Cancer. 1996; 77: 1254-62. http://dx.doi.org/10.1002/(SICI)1097-0142(19960401)77:7<1254::AID-CNCR5>3.0.CO;2-I

[21] Rees M, Tekkis PP, Welsh FK, O'Rourke T, John TG. Evaluation of long-term survival after hepatic resection for metastatic colorectal cancer: a multifactorial model of 929 patients. Ann Surg. 2008; 247: 125-35. PMid:18156932 http://dx.doi.org/10.1097/SLA.0b013e31815aa2c2

[22] Zakaria S, Donohue JH, Que FG, Farnell MB, Schleck CD, Ilstrup DM, Nagorney DM. Hepatic resection for colorectal metastases: value for risk scoring systems? Ann Surg. 2007; 246: 183-91. PMid:17667495 http://dx.doi.org/10.1097/SLA.0b013e3180603039

[23] Iwatsuki S, Dvorchik I, Madariaga JR, Marsh JW, Dodson F, Bonham AC, Geller DA, Gayowsky TJ, Fung JJ, Starzl TE. Hepatic resection for metastatic colorectal adenocarcinoma: a proposal of a prognostic scoring system. J Am Coll Surg. 1999; 189: 291-9. http://dx.doi.org/10.1016/S1072-7515(99)00089-7

[24] Van Custem E, Nordinger B, Adam R, Köhned CH, Pozzoe C, Poston G, Ychou M, Rougier P, on behalf of European Colorectal Metastases Treatment Group. Towards a pan-European consensus on the treatment of patients with colorectal liver metastases. Eur J Cancer. 2006; 42: 2212-21. PMid:16904315 http://dx.doi.org/10.1016/j.ejca.2006.04.012

[25] Poston GJ, Figueras J, Giuliante F, Nuzzo G, Sobrero AF, Gigot J-F, Nordinger B, Adam R, Graenberger T, Choti M, Bilckit AJ, Van Custem JD, Chiang JM, D'Angelica M. Urgent need for a new staging system in advanced colorectal cancer. J Clin Oncol. 2008; 26: 4828-33. PMid:18711170 http://dx.doi.org/10.1200/JCO.2008.17.6453

[26] Berge T, Linell F. Carcinoid tumours. Frequency in defined population during a 12-year period. Acta Pathol Microbiol Scand. 1976; 84(4): 322-30.

[27] Touzius JG, Kiely JM, Pitt SC, Rilling WS, Quebbeman EJ, Wilson SD, Pitt H. Neuroendocrine hepatic metastases: does aggressive management improve survival? Ann Surg. 2005; 241(5): 776-83.

http://dx.doi.org/10.1097/01.sla.0000161981.58631.ab

[28] Hodul P, Malafa M, Choi J, Kvols L. The role of cytoreductive hepatic surgery as an adjunct to the management of metastatic neuorendocrine carcinomas. Cancer Control. 2006; 13: 61-71.

[29] Lee PSY, Cheow PC, Teo JY, Ooi LLPJ. Surgical treatment of neuroendocrine liver metastases. Int J Hepatol $2012 ; 146590$. Epub 2012 Jan 26.

[30] Steinmueller T, Kianmanesh R, Falconi M, Scarpa A, Taal B, Kuekkeboom DJ, Lopes JM, Perren A, Nikou G, Delle Fave GF, O'Toole D. Frascati Concensus Conference Participants: Consensus guidelines for the management of patients with liver metastases from digestive (neuro)endocrine tumours: foregut, midgut, hindgut, and unknown primary. Neuroendocrinology. 2008; 87: 47-62. PMid:18097131 http://dx.doi.org/10.1159/000111037

[31] Sarmiento JM, Heywood G, Rubin J, Ilstrup DM, Nagorney DM, Qne FG. Surgical treatment of neuroendocrine metastases to the liver: a plea for resection to increase survival. J Am Coll Surg. 2003; 197: 29-37.

http://dx.doi.org/10.1016/S1072-7515(03)00230-8 
[32] Yao KA, Talamonti MS, Nemcek A, Angelos P, Chrisman H, Skarda J, Benson AB, Rao S, Joehl. Indications and results of liver resection and hepatic chemoembolization for metastatic gastrointestinal neuroendocrine tumours. Surgery. 2001; 130(4): 677-85. PMid:1 1602899 http://dx.doi.org/10.1067/msy.2001.117377

[33] Coppa J, Pulvirenti A, Schiavo M, Romito R, Collini P, Di Bartolomeo M, Fabbri A, Regalia E, Mazzaferro V. Resection versus transplantation for liver metastases from neuroendocrine tumours. Transplant Proc. 2001; 33(1-2): 1537-39. http://dx.doi.org/10.1016/S0041-1345(00)02586-0

[34] Jaeck D, Oussoultzoglou E, Bachellier P, Lemarque P, Weber JC, Nakano H, Wolf P. Hepatic metastases of gastroenteropancreatic neuroendocrine tumours: safe hepatic surgery. World J Surg. 2001; 25 (6): 689-92. PMid:11376398 http://dx.doi.org/10.1007/s00268-001-0014-7

[35] Nave H, M“ossinger E, Feist H, Lang H, Raab HR. Surgery as primary treatment in patients with liver metastases from carcinoid tumours: a retrospective, unicentric study over 13 years. Surgery. 2001; 129(2): 170-5. PMid:11174710 http://dx.doi.org/10.1067/msy.2001.110426

[36] Knox CD, Anderson CD, Lamps LW, RB Adkins, CW Pinson. Long-term survival after resection for primary hepatic carcinoid tumour. Ann Surg Oncol. 2003; 10(10): 1171-5. PMid:14654473 http://dx.doi.org/10.1245/ASO.2003.04.533

[37] Musunuru S, Chen H, Rajpal S, Stephani N, McDermott JC, Holen K, Rikkers LF, Weber SM. Metastatic neuroendocrine hepatic tumours: resection improves survival. Arch Surg. 2006; 141: 1000-4. PMid:17043278 http://dx.doi.org/10.1001/archsurg.141.10.1000

[38] Norton JA, Warren RS, Kelly MG, Zuraek MB, Jensen RT. Aggressive surgery for metastatic liver neuroendocrine tumours. Surgery. 2003; 134(6): 1057-65. PMid:14668741 http://dx.doi.org/10.1016/j.surg.2003.07.025

[39] Elias D, Lasser P, Ducreux M, Duvillard P, Ouellet JF, Dromain C. Liver resection (and associated extrahepatic resections) for metastatic welldifferentiated endocrine tumours: a 15-year single center prospective study. Surgery. 2003; 133(4): 375-82. PMid:12717354 http://dx.doi.org/10.1067/msy.2003.114

[40] Osborne DA, Zervos EE, Strosberg J, Boe BA, Malafa M, Rosemurgy AS. Improved outcome with cytoreduction versus embolization for symptomatic hepatic metastases of carcinoid and neuroendocrine tumours. Ann Surg Oncol. 2006; 13(4): 572-81. PMid:16511671 http://dx.doi.org/10.1245/ASO.2006.03.071

[41] Hibi T, Sano T, Sakamoto Y, Takahashi Y, Uemura N, Ojima H, Shimada K, Kosuge T. Surgery for hepatic neuroendocrine tumours: a single institutional experience in Japan. Jpn J Clin Oncol. 2007; 37 (2): 102-7. PMid:17234654 http://dx.doi.org/10.1093/jjco/hyl140

[42] Gomez D, Malik HZ, Al-Mukthar A, Menon KV, Toogood GJ, Lodge JPA, Prasad KR. Hepatic resection for metastatic gastrointestinal and pancreatic neuroendocrine tumours: outcome and prognostic predictors. HPB. 2007; 9(5): 345-51. PMid:18345317 http://dx.doi.org/10.1080/13651820701504199

[43] Landry CS, Scoggins CR, Mcmasters KM, Martin RCG. Management of hepatic metastasis of gastrointestinal carcinoid tumours. J Surg Oncol. 2008; 97 (3): 253-8. PMid:18264984 http://dx.doi.org/10.1002/jso.20957

[44] Chambers AJ, Pasieka JL, Dixon E, Rorstad O. The palliative benefit of aggressive surgical intervention for both hepatic and mesenteric metastases from neuroendocrine tumours. Surgery. 2008; 144(4): 645-53. PMid:18847650 http://dx.doi.org/10.1016/j.surg.2008.06.008

[45] Ahmed A, Turner G, King B, Jones L, Culliford D, McCance D, Ardill J. Midgut neuroendocrine tumours with liver metastases: results of the UKINETS study. Endocr-Relat Cancer. 2009, 16(3): 885-94. PMid:19458024 http://dx.doi.org/10.1677/ERC-09-0042

[46] Frilling A, Rogiers X, Malago M, Liedke OM, Kaun M, Broelsch CE. Treatment of liver metastases in patients with neuroendocrine tumours. Langenbeck's Arch Surg. 1998; 383: 62-70. http://dx.doi.org/10.1007/s004230050093

[47] Cancer Incidence, Mortality and Prevalence Worldwide in 2008. GLOBOCAN 2008. International Agency for Research on Cancer: World Health Organization [Internet]. IARC 2010 [cited 2012 Aug 22] Available from: http://www-dep.iarc.fr

[48] Borrego-Estella VM, Serrablo A. In: Borrego-Estella VM (ed.) Estudio de las metástasis hepáticas de cáncer colorrectal con rescate quirúrgico en un hospital de tercer nivel. Identificación de marcadores biológicos pronósticos. Salamanca: Colección VITOR; 2010. p12-9.

[49] Adam R, Chiche L, Aloia T, Elias D, Salmon R, Rivoire M, Jaeck D, Saric J, LeTreut YP, Belghiti J, Mantion G, Mentha G and the Association Française de Chirurgie. Hepatic resection for noncolorectal nonendocrine liver metastases. Analysis of 1452 patients and development of a prognostic model. Ann Surg. 2006; 244(4): 524-35. PMid:16998361

[50] Harrison LE, Brennan MF, Newman E, Fortner JG, Picardo A, Blumgart LH. Hepatic resection for noncolorectal, nonneuroendocrine metastases: a fifteen-year experience with ninety-six patients. Surgery. 1997; 121: 625-32. http://dx.doi.org/10.1016/S0039-6060(97)90050-7 
[51] Hemming AW, Sielaff TD, Gallinger S, Cattral MS, Taylor BR, Greig PD, Langer B. Hepatic resection of noncolorectal nonneuroendocrine metastases. Liver Transpl. 2000; 6: 97-101. PMid:10648585

[52] Laurent C, Rullier E, Feyler A, Masson B, Saric J. Resection of noncolorectal and nonneuroendocrine liver metastases: late meatastases are the only chance of cure. World J Surg. 2001; 25: 1532-6. PMid:11775186

[53] Yamada H, Katoh H, Kondo S, Okushiba S, Morikawa T. Hepatectomy from non-colorectal and non-neuroendocrine tumour. Anticancer Res. 2001; 21: 4159-62. PMid:11911311

[54] Cordera F, Rea DJ, Rodriguez-Davalos M, Hoskin TL, Nagorney DM, Que FG. Hepatic resection for noncolorectal, nonneuroendocrine metastases. J Gastrointest Surg. 2005; 9: 1361-70. PMid:16332495 http://dx.doi.org/10.1016/j.gassur.2005.07.032

[55] Ercolani G, Grazi GL, Ravaioli M, Ramacciato G, Cescon M, Varotti G, del Gaudio M, Vetrone G, Pinna AD. The role of liver resections for oncolorectal, nonneuroendocrine metastases: experience with 142 observed cases. Ann Surg Oncol. 2005; 12: 459-66. PMid:15886903 http://dx.doi.org/10.1245/ASO.2005.06.034

[56] Lendoire J, Moro M, Andriani O, Grondona J, Gil O, Raffin G, Silva J, Bracco R, Podestá G, Valenzuela C, Imventarza O, Pekoj J, De Santibañes E. Liver resection for non-colorectal, non-neuroendocrine metastases: analysis of a multicenter study from Argentina. HPB (Oxford). 2007; 9(6): 435-439. PMid:18345290 http://dx.doi.org/10.1080/13651820701769701

[57] Reddy SK, Barbas AS, Marroquin CE, Morse MA, Kuo PC, Clary BM. Resection of noncolorectal nonneuroendocrine liver metastases: a comparative analysis. J Am Coll Surg. 2007; 204: 372-82. PMid:17324770

http://dx.doi.org/10.1016/j.jamcollsurg.2006.12.019

[58] O'Rourke TR, Tekkis P, Yeung S, Fawcett J, Lynch S, Strong R, Wall D, John TG. Long-term results of liver resection for non-colorectal, non-neuroendocrine metastases. Ann Surg Oncol. 2008; 15: 207-218. PMid:17963007 http://dx.doi.org/10.1245/s10434-007-9649-4

[59] Lehner F, Ramackers W, Bektas H, Becker T, Klempnauer J. Liver resection for non-colorectal, non-neuroendocrine liver metastases - is hepatic resection justified as part of the oncosurgical treatment? Zentralbl Chir. 2009; 134: 430-436. PMid:19757343 http://dx.doi.org/10.1055/s-0029-1224601

[60] Marudanayagam R, Sandhu B, Thamara M, Perera PR, Taniere P, Coldham C, Bramhall S, Mayer D, Buckels J, Mirza D. Hepatic resection for non-colorectal, non-neuroendocrine, non-sarcoma metastasis: a single-centre experience. HPB (Oxford). 2011; 13(4): 286-92. PMid:21418135 http://dx.doi.org/10.1111/j.1477-2574.2010.00285.x

[61] Groeschl RT, Nachmany I, Steel JL, Reddy SK, Glazer ES, de Jong MC, Pawlik TM, Geller DA, Tsung A, Marsh JW, Clary BM, Curley SA, Gamblin TC. Hepatectomy for noncolorectal non-neuroendocrine metastatic cancer: a multi-institutional analysis. J Am Coll Surg. 2012; 214(5): 769-77. PMid:22425166 http://dx.doi.org/10.1016/j.jamcollsurg.2011.12.048

[62] Gold JS, DeMatteo RP. Combined surgical and medical therapy, the gastrointestinal stromal tumour model. Ann Surg. 2006; 244: 176-84. PMid:16858179 http://dx.doi.org/10.1097/01.sla.0000218080.94145.cf

[63] Miettinen M, El-Rifai W, HL Sobin L, Lasota J. Evaluation of malignancy and prognosis of gastrointestinal stromal tumours: a review. Hum Pathol. 2002; 33: 478-83. PMid:12094372 http://dx.doi.org/10.1053/hupa.2002.124123

[64] Miettinen M, Lasota J. Gastrointestinal stromal tumours: definition, clinical, histological, immunohistochemical, and molecular genetic features and differential diagnosis. Virchows Arch. 2001; 438: 1-12. http://dx.doi.org/10.1007/s004280000338

[65] Gomez D, Al-Mukthar A, Menon KV, Toogood GJ, Lodge JP, Prasad KR. Aggressive surgical resection for the management of hepatic metastases from gastrointestinal stromal tumours: a single centre experience. HPB. 2007; 9: 64-70. PMid:18333115 http://dx.doi.org/10.1080/13651820601156108

[66] DeMatteo RP, Lewis JJ, Leung D, Mudan SS, Woodruff JM, Brennan MF. Two hundred gastrointestinal stromal tumours: recurrence patterns and prognostic factors for survival. Ann Surg. 2000; 231: 51-8. PMid:10636102 http://dx.doi.org/10.1097/00000658-200001000-00008

[67] Husted TL, Neff G, Thomas MJ, Gross TG, Woodle ES, Buell JF. Liver transplantation for primary or metastatic sarcoma to the liver. Am J Transplant. 2006; 6: 392-7. PMid:16426326 http://dx.doi.org/10.1111/j.1600-6143.2005.01179.x

[68] Gold JS, DeMatteo RP: Combined surgical and medical therapy, the gastrointestinal stromal tumour model. Ann Surg. 2006; 244: 176-84. PMid:16858179 http://dx.doi.org/10.1097/01.sla.0000218080.94145.cf

[69] Turley RS, Peng PD, Reddy SK, Barbas AS, Geller DA, Marsh JW, Tsung A, Pawlik TM, Clary BM. Hepatic resection for metastatic gastrointestinal stromal tumours in the tyrosine kinase inhibitor era. Cancer 2012; 118(14): 3571-8. PMid:22086856 http://dx.doi.org/10.1002/cncr.26650

[70] Chen H, Pruitt A, Nicol TL, Gorgulu S, Choti MA. Complete hepatic resection of metastases from leiomyosarcoma prolongs survival. J Gastrointest Surg. 1998; 2: 151-5. http://dx.doi.org/10.1016/S1091-255X(98)80006-1 
[71] Lang H, Nussbaum KT, Kaudel P, Fruhauf N, Flemming P, Raab R. Hepatic metastases from leiomyosarcoma: a single center experience with 34 liver resections during a 15-year period. Ann Surg. 2000; 231: 500-5. PMid:10749609 http://dx.doi.org/10.1097/00000658-200004000-00007

[72] Shima Y, Horimi T, Ishikawa T, Ichikawa J, Okabayashi T, Nishioka Y, Hamada M, Shibuya Y, Ishii T, Ito M. Aggressive surgery for liver metastases from gastrointestinal stromal tumours. J Hepatobiliary Pancreat Surg. 2003; 10: 77-80. PMid:12827476

[73] Nunobe S, Sano T, Shimada K, Sakamoto Y, Kosuge T. Surgery including liver resection for metastatic gastrointestinal stromal tumours or gastrointestinal leiomyosarcomas. Jpn J Clin Oncol. 2005; 35: 338-41. PMid:15928191 http://dx.doi.org/10.1093/jjco/hyi091

[74] Pawlik TM, Vauthey JN, Abdalla EK, Pollock RE, Ellis LM, Curley SA. Results of a single-center experience with resection and ablation for sarcoma metastatic to the liver. Arch Surg. 2006; 141(6): 537-43. [discussion 543-4]. PMid:16785353 http://dx.doi.org/10.1001/archsurg.141.6.537

[75] Seifert JK, Weigel TF, Gonner U, Bottger TC, Junginger T. Liver resection for breast cancer metastases. Hepatogastroenterology 1999; 46: 2935-40. PMid:10576376

[76] Atalay G, Biganzoli L, Renard F, Paridaens R, Cufer T, Coleman R, Calvert AH, Gamucci T, Minisini A, Therasse P, Piccart MJ. Clinical outcome of breast cancer patients with liver metastases alone in the anthracycline-taxane era: A retrospective analysis of two prospective, randomised metastatic breast cancer trials. Eur J Cancer. 2003; 39: 2439-49. http://dx.doi.org/10.1016/S0959-8049(03)00601-4

[77] Adam R, Aloia T, Krissat J, Bralet MP, Paule B, Gachietti S, Delvart S, Azoulay D, Bismuth H, Castaing D. Is liver resection justified for patients with hepatic metastases from breast cancer? Ann Surg. 2006; 244: 897-908. PMid:17122615 http://dx.doi.org/10.1097/01.sla.0000246847.02058.1b

[78] Santoro E, Vitucci C, Carlini M, et al. [Liver metastasis of breast carcinoma. Results of surgical resection. Analysis of 15 operated cases]. Chir Ital. 2000; 52: 131-7. PMid:10832538

[79] Yoshimoto M, Tada T, Saito M, Takahashi K, Uchida Y, Kasumi F. Surgical treatment of hepatic metastases from breast cancer. Breast Cancer Res Treat. 2000; 59: 177-84. PMid:10817353 http://dx.doi.org/10.1023/A:1006398401352

[80] Selzner M, Morse MA, Vredenburgh JJ, Meyers WC, Clavien PA. Liver metastases from breast cancer: long-term survival after curative resection. Surgery. 2000; 127: 383-9. PMid:10776428 http://dx.doi.org/10.1067/msy.2000.103883

[81] Maksan SM, Lehnert T, Bastert G, Herfath C. Curative liver resection for metastasic breast cancer. Eur J Surg Oncol. 2000; 26: 209-12. PMid:10753531 http://dx.doi.org/10.1053/ejso.1999.0778

[82] Krisat J, Adam R, Casaign D, Azoulay D, Bismuth H. Prognostic factors after resection of liver metastases from breast [resumen]. Hep Pancreat Bil Surg. 2000; 2: 245.

[83] Pocard M, Pouillart P, Asselain B, Falcou MC, Salmon RJ. Resections hepatiques pour metastases de cancer du sein: resultats et facteurs pronostiques (65 cas). Ann Chir. 2001; 126: 413-20. http://dx.doi.org/10.1016/S0003-3944(01)00526-0

[84] Carlini M, Lonardo MT, Carboni F, Petric M, Vitucci C, Santoro R, Lepiane P. Liver metastases from breast cancer: Results of surgical resection. Hepatogastroenterology. 2002; 49: 597- 601.

[85] Elias D, Maisonnette F, Druet-Cabanac M, Ouellet JF, Guinebretiere JM, Spielmann M, Delaloge S. An attempt to clarify indications for hepatectomy for liver metastases from breast cancer. Am J Surg. 2003; 185: 158-64. http://dx.doi.org/10.1016/S0002-9610(02)01204-7

[86] Vlastos G, Smith DL, Singletary SE, Mirza NQ, Tuttle TM, Popat RJ, Curley SA, Ellis LM, Roh MS, Vauthey JN. Long term survival after an aggressive surgical approach in patients with breast cancer hepatic matastases. Ann Surg Oncol. 2004; 11: 869-74. PMid:15342348 http://dx.doi.org/10.1245/ASO.2004.01.007

[87] Sakamoto Y, Yamamoto J, Yoshimoto M, Kasumi F, Kosuge bT, Kokudo N, Makuuchi M. Hepatic resection for metastatic breast cancer: prognostic analysis of 34 patients. World J Surg. 2005; 29: 524-7. PMid:15770377 http://dx.doi.org/10.1007/s00268-004-7688-6

[88] Ercolani G, Grazi GL, Ravaioli M, Ramacciato G, Cescon M, Varotti G, Del Gaudio M, Vetrone G, Pinna AD. The role of liver resections for noncolorectal, nonneuroendocrine metastases: experience with 142 observed cases. Ann Surg Oncol. 2005; 12: 459-66. PMid:15886903 http://dx.doi.org/10.1245/ASO.2005.06.034

[89] D'Annibale M, Piovanello P, Cerasoli V, Lampioni N. Liver metastases from breast cancer: the role of surgical treatment. Hepatogastroenterology. 2005; 52: 1858-62. PMid:16334793

[90] Thelen A, Benckert C, Jonas S, Lopez-Hänninen E, Sehouli J, Neumann U, Rudolph B, Neuhaus P. Liver resection for metastases from breast cancer. J Surg Oncol. 2008; 97: 25-9. PMid:18041746 http://dx.doi.org/10.1002/jso.20911 
[91] Caralt M, Bilbao I, Cortes J, Escartín A, Lázaro JL, Dopazo C, Olsina JJ, Balsells J, Charco R. Hepatic resection for liver metastases as part of the "oncosurgical" treatment of metastatic breast cancer. Ann Surg Oncol 2008; 15: 2804-10. PMid:18670821 http://dx.doi.org/10.1245/s10434-008-0072-2

[92] Pawlik TM, Zorzi D, Abdalla EK, Clary BM, Gershenwald JE, Ross MI, Aloia TA, Curley SA, Camacho LH, Capussotti L, Elias D, Vauthey JN. Hepatic resection for metastatic melanoma: distinct patterns of recurrence and prognosis for ocular versus cutaneous disease. Ann Surg Oncol. 2006; 13: 712-20. PMid:16538410 http://dx.doi.org/10.1245/ASO.2006.01.016

[93] Rose DM, Essner R, Hughes TM, Tang PCY, Bilchik A, Wanek LA, Thompson JF, Morton DL. Surgical resection for metastatic melanoma to the liver: the John Wayne Cancer Institute and Sydney Melanoma Unit experience. Arch Surg. 2001; 136: 950-5. PMid:11485537 http://dx.doi.org/10.1001/archsurg.136.8.950

[94] Fuster D, Chiang S, Johnson G, Schuchter LM, Zhuang H, Alavi A. Is 18FDG PET more accurate than standard diagnostic procedure in the detection of suspected recurrent melanoma? J Nul Med. 2004; 45: 1323-7. PMid:15299056

[95] Stoelben E, Sturm J, Schmoll J, Keilholz U, Saeger HD. Resection of solitary liver metastases of malignant melanoma. Chirurg. 1995; 66: 40-3. PMid:7889789

[96] Wood TF, DiFronzo LA, Rose DM, Haigh PI, Stern SL, Wanek L. Does complete resection of melanoma metastatic to solid intra-abdominal organs improve survival? Ann Surg Oncol. 2001; 8: 658-62. PMid:11569781 http://dx.doi.org/10.1007/s10434-001-0658-4

[97] Essner R, Lee JH, Wanek LA, Itakura H, Morton DL. Contemporary surgical treatment of advanced-stage melanoma. Arch Surg. 2004; 139: 961-7. PMid:15381613 http://dx.doi.org/10.1001/archsurg.139.9.961

[98] Pawlik TM, Zorzi D, Abdalla EK, Clary BM, Gershenwald JE, Ross MI, Aloia TA, Curley SA, Camacho LH, Capussotti L, Elias D, Vauthey JN. Hepatic resection for metastatic melanoma: distinct patterns of recurrence and prognosis for ocular versus cutaneous disease. Ann Surg Oncol. 2006; 13: 712-20. PMid:16538410 http://dx.doi.org/10.1245/ASO.2006.01.016

[99] Ripley RT, Davis JL, Klapper JA, Mathur A, Kammula U, Royal RE, Yang JC, Sherry RM, Hughes MS, Libutti SK, White DE, Steinberg SM, Dudley ME, Rosenberg SA, Avital I. Liver resection for melanoma with postoperative tumour-inflitrating lymphocyte therapy. Ann Surg Oncol. 2010; 17(1): 163-70. PMid:19777192 http://dx.doi.org/10.1245/s10434-009-0677-0

[100] Wood TF, DiFronzo LA, Rose DM, Haigh PI, Stern SL, Wanek L, Essner R, MortonDL. Does complete resection of melanoma metastatic to solid intra-abdominal organs improve survival? Annals of Surgical Oncology. 2001; 8(8): 658-62. PMid:11569781 http://dx.doi.org/10.1007/s10434-001-0658-4

[101] Hsueh EC, Essner R, Foshag LJ, Ye X, Wang HJ, Morton DL. Prolonged survival after complete resection of metastases from intraocular melanoma. Cancer. 2004; 100(1): 122-9. PMid:14692032 http://dx.doi.org/10.1002/cncr.11872

[102] Crook TB, Jones Om, John TG, Rees M. Hepatic resection for malignant melanoma. Eur J Surg Oncol. 2006 ; 32 : $315-7$. PMid:16364589 http://dx.doi.org/10.1016/j.ejso.2005.10.006

[103] Herman P, Machado MAC, Montagnini AL, Albuquerque LA, Saad WA, Machado MC. Selected patients with metastatic melanoma may benefit from liver resction. World J Surg. 2007; 31: 171-4. PMid:17171491 http://dx.doi.org/10.1007/s00268-006-0375-z

[104] Chua TC, Saxena A, Morris DL. Surgical metastasectomy in AJCC Stage IV M1c melanoma patients with gastrointestinal and liver metastases. Ann Acad Med Singapore. 2010; 39: 634-9. PMid:20838706

[105] Ambiru S, Miyazaki M, Ito H, Nakagawa K, Shimizu H, Yoshidome H, Shimizu Y, Nakajima N. Benefits and limits of hepatic resection for gastric metastases. Am J Surg. 2001; 181: 279-83. http://dx.doi.org/10.1016/S0002-9610(01)00567-0

[106] Fujii K, Fujioka S, Kato K, Machiki Y, Kutsuna Y, Ishikawa A, Takamizawa J, Ko K, Yoshida. Resection of liver metastases from gastric adenocarcinoma. Hepatogastroenterology. 2001; 48: 368-371. PMid:11379310

[107] Imamura H, Matsuyama Y, Shimada R, Kubota M, Nakayama A, Kobayashi A et al. A study of factors influencing prognosis after resection of hepatic metastases from colorectal and gastric carcinoma. Am J Gastroenterol 2001; 96: 3178-84. PMid:11721768 http://dx.doi.org/10.1111/j.1572-0241.2001.05278.x

[108] Zacherl J, Zacherl M, Scheuba C, Steininger R, Wenzl E, Muhlbacher F, Jakesz R, Längle F. Analysis of hepatic resection of metastasis originating from gastric adenocarcinoma. J Gastrointest Surg 2002; 6: 682-9. http://dx.doi.org/10.1016/S1091-255X(01)00075-0

[109] Saiura A, Umekita N, Inoue S, Maeshiro T, Miyamoto S, Matsui Y, t Asakage M, Kitamura M. Clinicopathological features and outcome of hepatic resection for liver metastasis from gastric cancer. Hepatogastroenterology 2002; 49: 1062-5. PMid:12143202

[110] Okano K, Maeba T, Ishimura K, Karasawa Y, Goda F, Wakabayashi H, Usuki H, Maeta H. Hepatic resection for metastatic tumours from gastric cancer. Ann Surg. 2002; 235: 86-91. PMid:11753046 http://dx.doi.org/10.1097/00000658-200201000-00011 
[111] Shirabe K, Shimada M, Matsumata T, Higashi H, Yakeishi Y, Wakiyama S. Analysis of the prognostic factors for liver metastasis of gastric cancer after hepatic resection: a multiinstitutional study of the indications for resection. Hepatogastroenterology. 2003; 50: 1560-3. PMid:14571786

[112] Roh HR, Suh KS, Lee HJ, Yang HK, Choe KJ, Lee KU. Outcome of hepatic resection for metastatic gastric cancer. Am Surg. 2005; 71: 95-9. PMid:16022005

[113] Hirai I, Kimura W, Fuse A, Isobe H, Hachiya O, Moriya T et al. Surgical management for metastatic liver tumours. Hepatogastroenterology. 2006; 53:757-763. PMid:17086883

[114] Sakamoto Y, Sano T, Shimada K, Esaki M, Saka M, Fukagawa T, Katai H. Favourable indications for hepatectomy in patients with liver metastasis from gastric cancer. J Surg Oncol. 2007; 95: 534-539. PMid:17219383 http://dx.doi.org/10.1002/jso.20739

[115] Koga R, Yamamoto J, Ohyama S, Saiura A, Seki M, Seto Y, Yamaguchi T. Liver resection for metastatic gastric cancer: experience with 42 patients including eight longterm survivors. Jpn J Clin Oncol. 2007; 37: 836-42. PMid:17928333 http://dx.doi.org/10.1093/jjco/hym113

[116] Thelen A, Jonas S, Benckert C, Lopez-Hänninen E, Neumann U, Rudolph B, Schumacher G, Neuhaus P. Liver resection for metastatic gastric cancer. Eur J Surg Oncol. 2008; 34: 1328-34. PMid:18329229 http://dx.doi.org/10.1016/j.ejso.2008.01.022

[117] Cheon SH, Rha SY, Jeung HC, Im CK, Kim SH, Kim HR, Ahn JB, Roh JK, Noh SH, Chung HC. Survival benefit of combined curative resection of the stomach (D2 resection) and liver in gastric cancer patients with liver metastases. Ann Oncol. 2008; 19: 1146-53. PMid:18304963 http://dx.doi.org/10.1093/annonc/mdn026

[118] Morise Z, Sugioka A, Hoshimoto S, Kato T, Ikeda M, Uyami I, Horiguchi A, Miyakawa S. The role of hepatectomy for patients with liver metastases of gastric cancer. Hepatogastroenterology. 2008; 55: 1238-41. PMid:18795664

[119] Ueda K, Iwahashi M, Nakamori M, Nakamura M, Naka T, Ishida K, Ojima T, Yamaue H. Analysis of the prognostic factors and evaluation of surgical treatment for synchronous liver metastases from gastric cancer. Langenbecks Arch Surg. 2009; 394: 647-53. PMid:18343941 http://dx.doi.org/10.1007/s00423-008-0311-9

[120] Lindell G, Ohlsson B, Saarela A, Andersson R, Tranberg KG. Liver resection of noncolorectal secondaries. J Surg Oncol. 1998; 69: 66-70. http://dx.doi.org/10.1002/(SICI)1096-9098(199810)69:2<66::AID-JSO4>3.0.CO;2-G

[121] Di Carlo I, Grasso G, Patane D, Russello D, Latteri F. Liver metastases from lung cancer: is surgical resection justified? Ann Thorac Surg. 2003; 76: 291-3. http://dx.doi.org/10.1016/S0003-4975(03)00149-8

[122] Ercolani G, Ravaioli M, Grazi GL, Cescon M, Varotti G, Del Gaudio M, Vetrone G, Zanello M, Principe A, Pinna AD. The role of liver resections for metastases from lung carcinoma. HPB (Oxford). 2006; 8(2): 114-5. PMid:18333258 http://dx.doi.org/10.1080/13651820500471970

[123] Armstrong DK, Bundy B, Wenzel L, Huang HQ, Baergen MSR, Lele S, Copeland LJ, Walker JL, Burger RA. Intraperitoneal cisplatin and paclitaxel in ovarian cancer. N Engl J Med. 2006; 354(5): 34-43. PMid:16394300 http://dx.doi.org/10.1056/NEJMoa052985

[124] Yoon SS, Jarnagin WR, Fong Y, DeMatteo RP, Barakat RR, Blumgart LH, Chi DS. Resection of recurrent ovarian or fallopipan tube carcinoma involving the liver. Gynecol Oncol. 2003; 91: 383-8. PMid:14599870 http://dx.doi.org/10.1016/j.ygyno.2003.07.005

[125] Rasco DW, Assikis, Marshall F. Integrating metastasectomy in the managemente of advance urological malignancies-when are we in 2005? J Urol. 2006; 176: 1921-6. PMid:17070212 http://dx.doi.org/10.1016/j.juro.2006.07.003

[126] Alves A, Adam R, Majno P. Delvart V, Azoulay D, Castaing D, Bismuth H. Hepatic resection for metastatic renal tumours: is it worthwhile? Ann Surg Oncol. 2003; 10: 705-10. PMid:12839857 http://dx.doi.org/10.1245/ASO.2003.07.024

[127] Altendorf-Hofmann A, Scheele J. A critical review of the major indicators of prognosis after resection of hepatic metastases from colorectal carcinoma. Surg Oncol Clin N Am. 2003; 12: 165-92. http://dx.doi.org/10.1016/S1055-3207(02)00091-1

[128] Figueras J, Burdio F, Ramos E, Torras J, Llado L, Lopez-Ben S, Codina-Barreras A, Mojal S. Effect of subcentimeter nonpositive resection margin on hepatic recurrence in patients undergoing hepatectomy for colorectal liver metastases. Evidences from 663 liver resections. Annals of Oncology. 2007; 18: 1190-95. PMid:17434896 http://dx.doi.org/10.1093/annonc/mdm106

[129] Lordan JT, Karanjia ND. Size of surgical margin does not influence recurrence rates after curative liver resection for colorectal cancer liver metastases. Br J Surg. 2007; 94: 1133-8. PMid:17514637 http://dx.doi.org/10.1002/bjs.5762

[130] Poultsides GA, Schulick RD, Pawlik TM. Hepatic resection for colorectal metastases: the impact of surgical margin status on outcome. HPB. 2010; 12: 43-9. PMid:20495644 http://dx.doi.org/10.1111/j.1477-2574.2009.00121.x

[131] Elias D, Liberale G, Vernerey D, Pocard M, Ducreux M, Boige V, Malka D, Pignon JP, Lasser P. Hepatic and extrahepatic colorectal metastases: when resectable, their localization does not matter, but their total number has a prognostic effect. Ann Surg Oncol. 2005; 12: 900-9. PMid:16184442 http://dx.doi.org/10.1245/ASO.2005.01.010 
[132] Elias D, Ouellet JF, Bellon N. Extrahepatic disease does not contraindicate hepatectomy for colorectal liver metastases. Br J Surg. 2003; 90: 567-74. PMid:12734864 http://dx.doi.org/10.1002/bjs.4071

[133] Khatri VP, Petrelli NJ, Belghiti J. Extending the frontiers of surgical therapy for hepatic colorectal metastases: is there a limit? J Clin Oncol. 2005; 23: 8490-9. PMid:16230676 http://dx.doi.org/10.1200/JCO.2004.00.6155

[134] Minagawa M, Makuuchi M, Torzilli G, Takayama T, Kawasaki S, Kosuge T, Yamamoto J, Imamura H. Extension of the frontiers of surgical indications in the treatment of liver metastases from colorectal cancer: long-term results. Ann Surg. 2000; 231: 487-99. PMid:10749608 http://dx.doi.org/10.1097/00000658-200004000-00006

[135] Kanemitsu Y, Kato T, Hirai T, Yasui K. Preoperative probability model for predicting overall survival after resection of pulmonary metastases from colorectal cancer. Br J Surg. 2004; 91: 112-20. PMid:14716804 http://dx.doi.org/10.1002/bjs.4370

[136] Vauthey JN. Colorectal Liver Metastases: Treat Effectively Up Front and Consider the Borderline Resectable. J Clin Oncol 2007; 25(29): 4524-5. PMid:17925547 http://dx.doi.org/10.1200/JCO.2007.13.1136

[137] Adam R, de Haas RJ, Wicherts DA, Aloia TA, Delvart V, Azoulay D., Bismuth H, Castaing D. Is hepatic resection justified after chemotherapy in patients with colorectal liver metastases and lymph node involvement? J Clin Oncol. 2008; 26(22): 3672-80. PMid:18669451 http://dx.doi.org/10.1200/JCO.2007.15.7297

[138] Jaeck D. The significance of hepatic pedicle lymph nodes metastases in surgical management of colorectal liver metastases and of other liver malignancies. Ann Surg Oncol. 2003; 10: 1007-11. PMid:14597437 http://dx.doi.org/10.1245/ASO.2003.09.903

[139] Vauthey JN. The AHPBA 2006 Consensus Conference: Focus on Improving Resectability in Patients With Hepatic Colorectal Metastases. Medscape Oncology [Internet] 2006 Mar 31 [cited 2012 Aug 27]. Available from: http://www.medscape.org/viewarticle/524135

[140] Lehmann K, Rickenbacher A, AWeber, Pestalozzi BC, Clavien PA. Chemotherapy before liver resection of colorectal metastases: Friend or foe? Ann Surg. 2012; 255(2): 237-47. PMid:22041509 http://dx.doi.org/10.1097/SLA.0b013e3182356236

[141] Fong Y, Fortner J, Sun RL, Brennan MF, Blumgart LH. Clinical score for predicting recurrence after hepatic resection metastatic colorectal cancer: analysis of 1001 consecutive cases. Ann Surg. 1999; 230: 309-18. PMid:10493478 http://dx.doi.org/10.1097/00000658-199909000-00004

[142] Nondlinger B, Sorbye H, Glimelius B, Poston GJ, Schlag PM, Rougier P, Bechstein WO, Primrose JN, Walpole ET, Finch-Jones M, Jaeck D, Mirza D, Parks RW, Collette L, Praet M, Bethe U, Van Cutsem E, Scheithauer W, Gruenberger T. Perioperative chemotherapy with FOLFOX4 and surgery versus surgery alone for resectable liver metastases from colorectal cancer (EORTC Intergroup trial 40983): a randomised controlled trial. Lancet. 2008; 371: 1007-16.

http://dx.doi.org/10.1016/S0140-6736(08)60455-9

[143] Kooby DA, Stockman J, Ben-Porat L, Gonen M, Jarnagin WR, Dematteo RP, Tuorto S, Wuest D, Blumgart LH, Fong Y. Influence of transfusions on perioperative and long-term outcome in patients following hepatic resection for colorectal metastases. Ann Surg. 2003; 237: 860-70. PMid:12796583 http://dx.doi.org/10.1097/01.SLA.0000072371.95588.DA

[144] Strasberg SM, Belghiti J, Clavien PA, Gadzijev E, Garden JO, Lau WY, Makuuchi M, Strong RW. Terminology Committee of the International Hepato-Pancreato-Biliary Association: The Brisbane 2000 Terminology of Liver Anatomy and Resections. HPB 2000; 2: 333-9.

[145] de Haas RJ, Wicherts DA, Flores E, Azoulay D, Castaing D, Adam R. R1 resection by necessity for colorectal liver metastases: Is it still a contraindication to surgery? Ann Surg. 2008; 248(4): 626-37. PMid:18936576

[146] Gagner M, Rheault M, Dubuc J. Laparoscopic partial hepatectomy for liver tumor. Surg Endosc. 1992; 6: 99.

[147] Martin R, Paty P, Fong Y, Grace A, Cohen A, DeMatteo R, Jarnagin W, Blumgart L. Simultaneous liver and colorectal resections are safe for synchronous colorectal liver metastases. J Am Coll Surg. 2003; 197: 233-241. http://dx.doi.org/10.1016/S1072-7515(03)00390-9

[148] Tanaka K, Shimada H, Matsuo K, Nagano Y, Endo I, Sekido H. Outcome after simultaneous colorectal and hepatic resection for colorectal cancer with synchronous metastases. Surgery. 2004; 136: 650-659. PMid:15349115 http://dx.doi.org/10.1016/j.surg.2004.02.012

[149] Capussotti L, Ferrero A, Vigano L, Ribero D, Lo Tesoriere R, Polastri R. Major liver resection synchronous with colorectal surgery. Ann Surg Oncol. 2007; 14:195-201. PMid:17080238 http://dx.doi.org/10.1245/s10434-006-9055-3

[150] Weber JC, Bachellier P, Oussoultzoglow E, Jaeck D. Simultaneous resection of colorectal primary tumor and synchronous liver metastases. Br J Surg. 2003; 90: 956. PMid:12905548 http://dx.doi.org/10.1002/bjs.4132

[151] Mentha G, Majno PE, Andres A, Rubbia-Brandt L, Morel P, Roth AD. Neoadjuvant chemotherapy and resection of advanced synchronous liver metastases before treatment of the colorectal primary. Br J Surg. 2006; 93(7): 872-8. PMid:16671066 http://dx.doi.org/10.1002/bjs.5346 
[152] Adam R, Delvart V, Pascal G, Castaing D, Azoulay D, Giacchetti S, Paule B, Kunstlinger F, Ghémard O, Levi F, Bismuth H. Rescue surgery for unresectable colorectal liver metastases downstaged by chemotherapy: a model to predict longterm survival. Ann Surg. 2004; 240: 644-57. PMid:15383792

[153] Benoist S, Brouquet A, Penna C, Julié C, El Hajjam M, Chagnon S, Mitry E, Rougier P, Nordlinger B. Complete response of colorectal liver metastases after chemotherapy: does it mean cure? J Clin Oncol. 2006; 20(24): 3939-45. PMid:16921046 http://dx.doi.org/10.1200/JCO.2006.05.8727

[154] Abdalla EK, Adam R, Bilchik AJ, Jaeck D, Vauthey JN, Mahvi R. Improving resectability of hepatic colorectal metastases: Expert consensus statement. Annals of Surgical Oncology. 2006; 13(10): 1271-80. PMid:16955381 http://dx.doi.org/10.1245/s10434-006-9045-5

[155] Donadon M, Ribero D, Morris-Stiff G, Abdalla EK, Vauthey JN. New paradigm in the management of liver-only metastases from colorectal cancer. Gastrointest Cancer Res. 2007; 1(1): 20-7. PMid:19262699

[156] Garden OJ, Rees M, Poston GJ, Mirza D, Saunders M, Ledermann J, Primrose JN, Parks RW. Guidelines for resection of colorectal cancer liver metastases. Gut. 2006; 55 (Suppl 3): iii1-iii8. PMid:16835351 http://dx.doi.org/10.1136/gut.2006.098053

[157] Benoist S, Pautrat K, Mitry E, Rougier R, Penna C, Nordinger B. Treatment strategy for patients with colorectal cancer and synchronous irresectable liver metastases. Br J Surg. 2005; 92: 1155-60. PMid:16035135 http://dx.doi.org/10.1002/bjs.5060

[158] de Haas R J, Wicherts DA, Andreani P, Pascal G, Saliba F, Ichai P, Adam R, Castaing D, Azoulay D. Impact of expanding criteria for resectability of colorectal metastases on short- and long-term outcomes after hepatic resection. Ann Surg. 2011; 253(6): 1069-79. PMid:21451388 http://dx.doi.org/10.1097/SLA.0b013e318217e898

[159] Laurent C, Sa Cunha A, Couderc P, Rullier E, Saric J. Influence of postoperative morbidity on long-term survival following liver resection for colorectal metastases. Br J Surg. 2003; 90(9): 1131-6. PMid:12945082 http://dx.doi.org/10.1002/bjs.4202

[160] Makuuchi M, Thai BL, Takayasu K, Takayama T, Kosuge T, Gunven P, Yamazaki S, Hasegawa H, Ozaki H. Preoperative portal embolization to increase safety of major hepatectomy for hilar bile duct carcinoma: a preliminary report. Surgery. 1990; 107: 521-7. PMid:2333592

[161] Ribero D, Abdallah EK, Madoff DC, Donadon M, Loyer EM, Vauthey JN. Portal vein embolization before major hepatectomy and its effects on regeneration, resectability and outcome. Br J Surg. 2007; 94: 1386-96. PMid:17583900 http://dx.doi.org/10.1002/bjs.5836

[162] Abdallah EK, Hicks ME, Vauthey JN. Portal vein embolization: rationale, technique and future prospects. Br J Surg. 2001; 88: 165-75. PMid:11167863 http://dx.doi.org/10.1046/j.1365-2168.2001.01658.x

[163] Azoulay D, Castaing D, Smail A, Adam R, Cailliez V, Laurent A, Lemoine A, Bismuth H. Resection of non-resectable liver metastases from colorectal cancer after percutaneous portal vein embolization. Ann Surg. 2000; 4: 480-86. http://dx.doi.org/10.1097/00000658-200004000-00005

[164] Adam R, Laurent A, Azoulay D, Castaing D, Bismuth H. Two-stage hepatectomy: a planned strategy to treat irresectable liver tumors. Ann Surg. 2000; 232: 777-85. PMid:11088072 http://dx.doi.org/10.1097/00000658-200012000-00006

[165] Jaeck D, Oussoultzoglou E, Rosso E, Greget M, Weber JC, Bachellier P. Two-stage hepatectomy procedure combined with portal vein embolization to achieve curative resection for initially unresectable multiple and bilobar colorectal liver metastases. Ann Surg. 2004; 240: 1037-49. PMid:15570209 http://dx.doi.org/10.1097/01.sla.0000145965.86383.89

[166] Clavien PA, Petrowsky H, DeOliveira ML, Graf R. Strategies for safer liver surgery and partial liver transplantation. N Engl J Med. 2007; 356(15): 1545-59. PMid:17429086 http://dx.doi.org/10.1056/NEJMra065156

[167] Kianmanesh R, Farges O, Abdalla EK, Sauvanet A, Ruszniewski, Belghiti J. Right portal vein ligation: a new planned two-step all-surgical approach for complete resection of primary gastrointestinal tumors with multiple bilateral liver metastases. J Am Coll Surg. 2003; 197: 164-70. http://dx.doi.org/10.1016/S1072-7515(03)00334-X

[168] Brouquet A, Abdalla EK, Kopetz S, Garrett CR, Overman MJ, Eng C, Andreou A, Loyer EM, Madoff DC, Curley SA, Vauthey JN. High survival rate after two-stage resection of advanced colorectal liver metastases: responsebased selection and complete resection define outcome. J Clin Oncol. 2011; 29: 1083-90. PMid:21263087 http://dx.doi.org/10.1200/JCO.2010.32.6132

[169] Narita M, Oussoultzoglou E, Jaeck D, Fuchschuber P, Rosso E, Pessaux P, Marzano E, Bachellier P. Two-stage hepatectomy for multiple bilobar colorectal liver metastases. Br J Surg. 2011; 98(10): 1463-75. PMid:21710481 http://dx.doi.org/10.1002/bjs.7580

[170] Schnitzbauer AA, Lang SA, Goessmann H, Nadalin S, Baumgart J, Farkas SA, Fichtner-Feigl S, Lorf T, Goralcyk A, Hörbelt R, Kroemer A, Loss M, Rümmele P, Scherer MN, Padberg W, Königsrainer A, Lang H, Obed A, Schlitt HJ. Right portal vein ligation combined with in situ splitting induces rapid left lateral liver lobe hypertrophy enabling 2-staged extended right hepatic resection in small-for-size settings. Ann Surg. 2012; 255(3): 405-14. PMid:22330038 http://dx.doi.org/10.1097/SLA.0b013e31824856f5 
[171] Aloia TA, Vauthey JN. Associating liver partition and portal vein ligation for staged hepatectomy (ALPPS): What is gained and what is lost? Annals of Surgery. 2012; 256(3): e9. PMid:22868369 http://dx.doi.org/10.1097/SLA.0b013e318265fd3e

[172] Jain HA, Bharathy KGS, Negi SS. Associating Liver Partition and Portal Vein Ligation for Staged Hepatectomy: Will the morbidity of an additional surgery be outweighed by better patient outcomes in the long-term? Annals of Surgery. 2012; 256(3): e10. PMid:22868375 http://dx.doi.org/10.1097/SLA.0b013e318265fe4f

[173] Narita M, Oussoultzoglou E, Ikai I, Bachellier P, Jaeck D. Right portal vein ligation combined with in situ splitting induces rapid left lateral liver lobe hypertrophy enabling 2-staged extended right hepatic resection in small-for-size settings. Annals of Surgery 2012; 256(3): e7-8. PMid:22868374 http://dx.doi.org/10.1097/SLA.0b013e318265fd51

[174] Santibañes E, Clavien PA. Playing play-doh to prevent postoperative liver failure: The "ALPPS" approach. Annals of Surgery. 2012; 256(3): 415-7. PMid:22330039 http://dx.doi.org/10.1097/SLA.0b013e318248577d

[175] Andriani OC. Long-term results with associating liver partition and portal vein ligation for staged hepatectomy (ALPPS). Annals of Surgery. 2012; 256(3): e5. PMid:22842129 http://dx.doi.org/10.1097/SLA.0b013e318265fbbe

[176] Clavien PA, Santibañes E. The ALPPS: Time to explore! Ann Surg. 2012; 256(3): e18-9. http://dx.doi.org/10.1097/SLA.0b013e318266235d

[177] Machado MAC, Makdissi FF, Surjan RC. Totally laparoscopic ALPPS is feasible and may be worthwhile. Annals of Surgery 2012; 256(3): e13. PMid:22842130 http://dx.doi.org/10.1097/SLA.0b013e318265ff2e

[178] Conrad C, Shivathirthan N, Camerlo A, Strauss C, Gayet B. Laparoscopic portal vein ligation with in situ liver split for failed portal vein embolization. Annals of Surgery 2012; 256(3): e14-5. PMid:22895353 http://dx.doi.org/10.1097/SLA.0b013e318265ff44

[179] Solbiati L, Livraghi T, Goldberg SN, et al Percutaneous radiofrequency ablation of hepatic metastases from colorectal cancer: long-term results in 117 patients. Radiology 2001; 221: 159-66. PMid:11568334 http://dx.doi.org/10.1148/radiol.2211001624

[180] Sorensen SM, Mortensen FV, Nielsen DT. Radiofrequency ablation of colorectal liver metastases: long-term survival. Acta Radiol. 2007; 48: 253-8. PMid:17453491 http://dx.doi.org/10.1080/02841850601161539

[181] Machi J, Oishi AJ, Sumida K, Sakamoto K, Furumoto NL, Oishi RH, Kylstra JW. Long-term outcome of radiofrequency ablation for unresectable liver metastases from colorectal cancer: evaluation of prognostic factors and effectiveness in first- and second-line management. Cancer J. 2006; 12: 318-26. PMid:16925977 http://dx.doi.org/10.1097/00130404-200607000-00011

[182] Konopke R, Roth J, Volk A, Pistorius S, Folprecht G, Zoephel K, Schuetze C, Laniado M, Saeger HD, Kersting S. Colorectal Liver Metastases: an Update on Palliative Treatment Options. J Gastrointestin Liver Dis. 2012; 21(1): 83-91. PMid:22457864

[183] Kennedy JE. High-intensity focused ultrasound in the treatment of solid tumours. Nat Rev Cancer. 2005; 5: 321-7. PMid:15776004 http://dx.doi.org/10.1038/nrc1591

[184] Al-Asfoor A, Federowicz Z, Lodge M. Resection versus no intervention or other surgical interventions for colorectal cancer liver metastases. Cochrane Database Syst Rev. 2008; 16(2): CD006039.

[185] Azoulay D, Eshkenazy R, Andreani P, Castaing D, Adam R, Ichai P, Naili S, Vinet E, Saliba F, Lemoine A, Gillon MC, Bismuth H. In situ hypothermic perfusion of the liver versus standard total vascular exclusion of complex liver resection. Ann Surg. 2005; 241: 277-85. PMid:15650638 http://dx.doi.org/10.1097/01.sla.0000152017.62778.2f

[186] Hemming AW, Chari RS, Cattral MS. Ex vivo liver resection. Can J Surg. 2000; 43(3): 222-4. PMid:10851418

[187] Lodge JPA, Ammori BJ, Prasad KR, Bellamy MC. Ex vivo and in situ resection of inferior vena cava with hepatectomy for colorectal metastases. Ann Surg. 2000; 231(4): 471-9. PMid:10749606 http://dx.doi.org/10.1097/00000658-200004000-00004

[188] Hemming AW, Reed AI, Langham MR Jr, Fujita S, Howard RJ. Combined resection of the liver and inferior vena cava for hepatic malignancy. Ann Surg. 2004; 239: 712-21. PMid:15082976 http://dx.doi.org/10.1097/01.sla.0000124387.87757.eb

[189] Langenhoff BS, Krabbe PF, Ruers TJ. Efficacy of follow-up after surgical treatment of colorectal liver metastases. Eur J Surg Oncol. 2009; 35: 180-6. PMid:18691847 http://dx.doi.org/10.1016/j.ejso.2008.06.189

[190] Petrelli N. Perioperative or adjuvant therapy for resectable colorectal hepatic metastases. J Clin Oncol. 2008; 26(30): $4862-3$. PMid:18794535 http://dx.doi.org/10.1200/JCO.2008.18.5868

[191] Smith MD, McCall JL. Systematic review of tumour number and outcome after radical treatment of colorectal liver metastases. Br J Surg. 2009; 96(10): 1101-13. PMid:19787755 http://dx.doi.org/10.1002/bjs.6735

[192] Söreide JA, Eiriksson K, Sandvik O, Viste A, Horn A, Johnsen G, Grønbech JE. Surgical treatment of liver metastases from colorectal cancer. Br J Surg. 2008; 128: 50-3.

[193] Petrowsky H, Gonen M, Jarnagin W, Lorenz M, DeMatteo R, Heinrich S, Encke A, Blumgart L, Fong Y. Second liver resections are safe and effective treatment for recurrent hepatic metastases from colorectal cancer: a bi - institutional analysis. Ann Surg 2002; 235: 863-71. PMid:12035044 http://dx.doi.org/10.1097/00000658-200206000-00015

[194] Yamamoto J, Kosuge T, Shimada K, Yamasaki S, Moriya Y, Sugihara K. Repeat liver resection for recurrent colorectal liver metastases. Am J Surg. 1999; 178: 275-81. http://dx.doi.org/10.1016/S0002-9610(99)00176-2 
[195] Adam R, Pascal G, Azoulay D, Tanaka K, Castaing D, Bismuth H. Liver resection for colorectal metastases: the third hepatectomy. Ann Surg. 2005; 238: 871-83. PMid:14631224 http://dx.doi.org/10.1097/01.sla.0000098112.04758.4e

[196] Ramia JM, Figueras J, De la Plaza R, García-Parreño J. Resección de metástasis hepáticas en presencia de enfermedad extrahepática. Cir Esp. 2012; 90(8):483-9. PMid:22682358 http://dx.doi.org/10.1016/j.ciresp.2012.01.010

[197] Elias D, Sideris L, Pocard M, Ouellet JF, Boige V, Lasser P, et al. Results of R0 resection for colorectal liver metastases associated with extrahepatic disease. Ann Surg Oncol. 2004; 11:274-80. PMid:14993022 http://dx.doi.org/10.1245/ASO.2004.03.085

[198] Yang YYL, Fleshman J, Strasberg S. Detection and management of extrahepatic colorectal cancer in patients with resectable liver metastases. J Gastrointest Surg. 2007; 11:929-44. PMid:17593417 http://dx.doi.org/10.1007/s11605-006-0067-x

[199] Adam R, De Haas RJ, Wicherts DA, Aloia TA, Delvart V, Azoulay D. Is hepatic resection justified after chemotherapy in patients with colorectal liver metastases and lymph node involvement? J Clin Oncol. 2008; 26:3672-80. PMid:18669451 http://dx.doi.org/10.1200/JCO.2007.15.7297

[200] Adam R, De Haas RJ, Wicherts D, Vibert E, Salloum C, Azoulay D, Castaing D. Concomitant extrahepatic disease in patients with colorectal liver metastases. When is there a place for surgery? Ann Surg. 2011; 253: 349-59. PMid:21178761 http://dx.doi.org/10.1097/SLA.0b013e318207bf2c

[201] Elias D, Liberale G, Vernerey D, Pocard M, Ducreux M, Boige V, Malka D, Pignon JP, Lasser P. Hepatic and extrahepatic colorectal metastases: when resectable, their localization does not matter, but their total number has a prognostic effect. Ann Surg Oncol. 2005; 12: 900-9. PMid:16184442 http://dx.doi.org/10.1245/ASO.2005.01.010

[202] Carpizo D, Chandrakanth A, Jarnagin W, DeMatteo R, Fong Y, Gonen M, Blumgart L, D'Angelica M. Liver resection for metastasic colorectal cancer in patients with concurrent extrahepatic disease: results in 127 patients treated at a single center. Ann Surg Oncol. 2009; 16: 2138-46. PMid:19495884 http://dx.doi.org/10.1245/s10434-009-0521-6

[203] Carpizo DR, D' Angelica M. Liver resection for metastatic colorectal cancer in the presence of extrahepatic disease. Lancet Oncol. 2009; 10: 801-9. http://dx.doi.org/10.1016/S1470-2045(09)70081-6

[204] Aoki T, Umekita N, Tanaka S, Noda K, Warabi M, Kitamura M. Prognostic value of concomitant resection of extrahepatic disease in patients wih liver metastases of colorectal origin. Surgery. 2008; 143: 706-14.

PMid:18549886 http://dx.doi.org/10.1016/j.surg.2008.02.004 